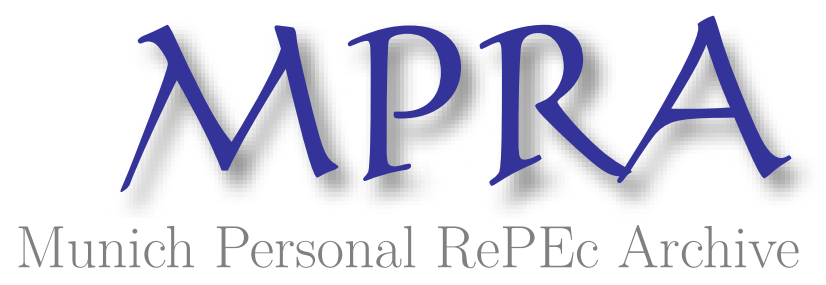

\title{
Thin capitalisation rules: A second-best solution to the cross-border debt bias?
}

Kayis-Kumar, Ann

UNSW Australia

25 February 2015

Online at https://mpra.ub.uni-muenchen.de/72031/

MPRA Paper No. 72031, posted 18 Jun 2016 04:38 UTC 


\title{
THIN CAPITALISATION RULES: A SECOND-BEST SOLUTION TO THE CROSS- BORDER DEBT BIAS?
}

\author{
Ann Kayis-Kumar*
}

\begin{abstract}
One of the most significant trends in the evolution of global tax systems has been the rise from relative obscurity of thin capitalisation rules, which are perceived as anti-avoidance rules which limit tax base erosion from cross-border interest deductions. However, over the same timeframe, innovations to financial instruments have challenged the traditional financial and legal distinctions between debt and equity, which in the cross-border setting has exposed the prevalence of economic inefficiencies in the design of the international tax system.
\end{abstract}

This paper approaches the issue of thin capitalisation from a novel perspective by conceptualising the cross-border debt bias as the 'disease' and thin capitalisation as merely the 'symptom'. Despite their prevalence, it is unclear whether thin capitalisation rules: (1) attain tax neutrality (specifically, do these rules mitigate the debt bias); (2) are effective in both theory and practice.

This provides the basis to examine whether a cross-border manifestation of a fundamental reform could eliminate the need for existing thin capitalisation rules, which are presently a second-best solution to the tax-induced cross-border debt bias. Accordingly, this paper: (1) considers reforms traditionally designed to address the domestic debt bias; specifically, the allowance for corporate equity (ACE), comprehensive business income tax (CBIT), combined ACE-CBIT and allowance for corporate capital; (2) examines the literature and implementation experience of the ACE, the only one of these fundamental reforms which has been experimented with in practice, to consider whether it is effective in both theory and practice; (3) presents the possibility of extending the combined ACECBIT to the cross-border context as an alternative to thin capitalisation rules.

\footnotetext{
* BCom(Finance)/LLB(Hons) (UNSW), PhD (UNSW, in progress), School of Taxation and Business Law, UNSW Australia, Solicitor of the Supreme Court of New South Wales and High Court of Australia, a.kayis@ unsw.edu.au. The author is deeply grateful to her PhD supervisors, Professor Neil Warren and Professor John Taylor, for their ongoing support and invaluable insights. This paper first appeared in Australian Tax Forum (2015) 30(2) 299-355 and is reprinted with kind permission of the Tax Institute.
} 


\section{INTRODUCTION}

This paper approaches the issue of thin capitalisation from a novel perspective by conceptualising the cross-border debt bias as the 'disease' and thin capitalisation as merely the 'symptom'. The overarching question guiding this paper is whether, given the opportunity to 'start over', the taxinduced cross-border debt bias would be better addressed by retaining thin capitalisation rules in their current form or whether an alternative reform would be more suited to dealing with this 'disease'.

The cross-border tax-induced debt bias incentivises MNEs to finance their high-tax jurisdiction affiliates with excessive debt, thereby reducing their tax liability in those jurisdictions. International debt shifting through this phenomenon of 'hidden equity capitalisation' (or 'thin capitalisation') lies at the core of (aggressive) international tax planning. Currently, tax authorities address tax revenue base erosion by restricting interest relief in cross-border financial transactions by MNEs. This is achieved through provisions such as 'thin capitalisation rules'. Thin capitalisation rules seek to prevent the erosion of the tax revenue base and seem to have reduced debt ratios. However, leading commentators approach these results sceptically, suggesting that rather than mitigating the debt bias, these rules simply encourage levels of debt at the specified threshold debt-equity ratios.

Of course, in the absence of international tax coordination, full tax neutrality cannot be obtained, as tax rates and systems will still differ. However, it is still possible to encourage neutrality between equity and debt financing from a tax point of view ('funding neutrality') as a second-best solution. Funding neutrality may be achieved by implementing fundamental reforms designed to address the debt bias by equalising the tax treatment of debt and equity financing.

Accordingly, section 2 begins by observing that thin capitalisation legislation merely targets the 'symptom' of debt shifting, rather than the underlying 'disease' of the tax-induced cross-border debt bias. This section examines the background, practice and issues in practice associated with thin capitalisation rules. In particular, highlighting the thin capitalisation rules' departures from good tax design and examining the literature that challenging the assumption that these rules mitigate the debt bias. This is supplemented by empirical evidence which suggests that thin capitalisation rules considerably complicate corporate tax systems, reduce investment, are usually ad-hoc and not well targeted, and are often avoided by MNEs that can exploit hybrid instruments and international differences in definitions of debt and equity.

Section 3 of this paper considers reforms traditionally designed to address the domestic debt bias; specifically, the allowance for corporate equity (ACE), comprehensive business income tax (CBIT), combined ACE-CBIT and allowance for corporate capital (ACC). The focus of this section is on examining the literature and implementation experience of the ACE, which is the only fundamental reform to have been experimented with in practice. This section also presents the possibility of implementing a combined ACE-CBIT in the cross-border context as an alternative to thin capitalisation rules.

Finally, section 4 summarises the findings of this paper and includes areas for further research. 


\section{THIN CAPITALISATION RULES: ADDRESSING DOMESTIC TAX REVENUE BASE EROSION}

\subsection{BACKGROUND}

Even though the cross-border issue cannot be isolated from the rest of the tax system, ${ }^{1}$ the focus of this paper is the cross-border debt bias because the debt bias is most problematic in this context. The tax-induced cross-border debt bias incentivises behavioural responses to take advantage of the international classification differences between debt and equity, ${ }^{2}$ and distorts multinational enterprises ('MNEs') corporate financing decisions.

MNEs are clearly at an advantage, with access to global debt and equity markets; various jurisdictions' tax rates; and, various tax systems in general. In the absence of international tax coordination, these opportunities are nearly impossible to eliminate. On the other hand, policymakers are increasingly faced with the competing objectives of remaining internationally competitive and encouraging foreign investment while also maintaining the integrity of their national tax bases.

Thin capitalisation rules arose from governments' concerns regarding tax base erosion and are one species of a plethora of various legislative rules restricting cross-border interest deductibility. ${ }^{3}$ These rules' strong emphasis on revenue base protection has resulted in an exponentially increasing popularity internationally, ${ }^{4}$ as shown in Figure 1 below:

Figure 1

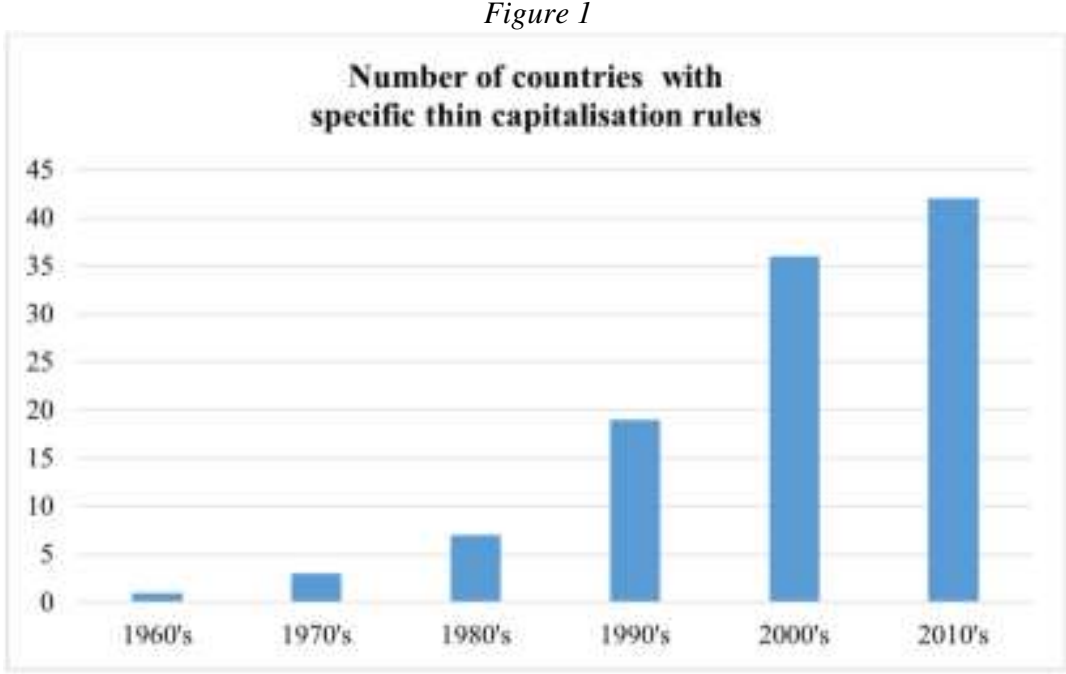

However, it is necessary to make a two-fold clarification. First, no two thin capitalisation regimes are the same. Second, the term 'thin capitalisation' itself is not an exact legal term, rather it has both a narrow and a broad meaning. The narrow definition of thin capitalisation relates to the excessive use of debt financing compared to equity financing (or asset bases). ${ }^{5}$ On the other hand, the broad

\footnotetext{
${ }^{1}$ Grubert H and Altshuler R, 'Corporate Taxes in the World Economy: Reforming the Taxation of Cross-Border Income', in: Diamond J and Zodrow G (eds.) Fundamental Tax Reform: Issues, Choices, and Implications (Cambridge, MA: MIT Press, 2008), 319-321.

${ }^{2}$ Desai MA, Testimony before the US Senate Committee on Finance and the US House Committee on Ways and Means (13 July 2011); available at: http://www.finance.senate.gov/imo/media/doc/DesaiTestimonyFinal.pdf, 4.

${ }^{3}$ A full synthesis of all cross-border restrictions on interest deductibility is beyond the scope of this paper; however, a starting point is Dourado A and de la Feria R, 'Thin Capitalization Rules in the Context of the CCCTB' (Working Paper 08/04, Oxford University Centre for Business Taxation, 2008).

${ }^{4}$ Blouin et al observe that 27 out of 54 countries sampled had implemented specific thin capitalisation rules: Blouin J, Huizinga H, Laeven L and G Nicodème, 'Thin Capitalization Rules and Multinational Firm Capital Structure' (IMF Working Paper WP/14/12, January 2014), 7. Within a decade, this increased to 42 of the 54 countries sampled.

${ }^{5}$ In this context, thin capitalisation rules places formal restrictions on the deductibility of interest paid by MNEs, with the portion that is deemed 'excessive' being disallowed or, in some cases, requalified as dividends. This is aimed at MNEs using, for example, internal debt as a means to shift profits from high-tax to low-tax jurisdictions: see Helminen M,
} 
definition casts a wider net to also include hybrid financing. ${ }^{6}$ The literature has given relatively little attention to the implications on the effectiveness of thin capitalisation rules due to the advent of hybrid financing. ${ }^{7}$ Studies that do exist focus on the European context and make no mention of jurisdictions such as Australia. ${ }^{8}$

Even though some empirical findings point to Base Erosion and Profit Shifting ('BEPS') declining over the past decade, ${ }^{9}$ leading to scepticism regarding the OECD's current focus on the BEPS project, ${ }^{10}$ the OECD's focus on transfer pricing ${ }^{11}$ reflects policymakers and other leading academics' concern. ${ }^{12}$ Indeed, the OECD is currently developing best practice recommendations for the design of thin capitalisation rules through Action 4 of its BEPS project, expected to be made available by late$2015 .^{13}$ This is almost 3 decades in the making. By way of background, the most recent OECD report on thin capitalisation rules was published in $1986^{14}$ and omitted guidance on how thin capitalisation rules could best be designed. ${ }^{15}$

International Tax Law Concept of Dividend: Issue 36 of Series on international taxation, (Great Britain: Kluwer Law International, 2010)., 321-322, and footnotes cited therein; see also; Arnold B, 'General Report: Deductibility of Interest and Other Financing Charges in Computing Income', in: International Fiscal Association, Deductibility of interest and other financing charges in computing income, Cahiers de droit fiscal international, 79a (Toronto, Canada: Kluwer Law International, 1994) 491, 512; Piltz D, General Report in Cahiers De Droit Fiscal International: International Aspects of Thin Capitalisation (1996) XXXIb International Fiscal Association, Geneva Congress, 89.

${ }^{6}$ Hybrid financing presents a fundamental challenge to traditional corporate financing principles because in practice it is becoming increasingly difficult for governments to classify financial instruments, as many have some of the traditional elements of both debt and equity: see Lüthi D, 'Thin capitalisation of companies in international tax law' (1991) 19(10) Intertax 446, 447. The economics literature assumes that corporate debt shields are limited in practice due to the associated default risk from excess leverage. Further, when focusing on intra-group debt and equity financing, bilateral double tax conventions are usually effective for tax harmonisation purposes. However, if debt and equity are merely tax-related labels, then this is no longer a valid assumption: Shaviro DN, 'Simplifying Assumptions: How Might the Politics of Consumption Tax Reform Affect (Impair) the End Product?', in: Diamond J and Zodrow G (eds.) Fundamental Tax Reform: Issues, Choices, and Implications (Cambridge, MA: MIT Press, 2008) 75-124, 98. Due to the advent of financial engineering, it is possible to separate tax labels from economic substance, thereby giving a corporate financial instrument a specific tax characteristic while simultaneously and independently manufacturing a particular set of economic relationships between the investors: see further, Devereux, 518; Aschauer E, Eberhartinger E, Panny W, 'Cross-border hybrid finance and tax planning: does international coordination work?', in: Zagler M (ed.), International Tax Coordination - An interdisciplinary perspective on virtues and pitfalls (New York: Routledge, 2010), 115-133; Klostermann M, 'The Consequences of Hybrid Finance in Thin Capitalization Situations: An Analysis of the Substantive Scope of National Thin Capitalization Rules with special Emphasis on Hybrid Financial Instruments' (Discussion Papers SFB International Tax Coordination No 22, WU Vienna University of Economics and Business, July 2007); Sørensen PB and Johnson S, Chapter 9: Taxing Capital Income - Options for Reform in Australia, Melbourne Institute, Australia's Future Tax and Transfer Policy Conference, June 2009, 203.

${ }^{7}$ Although leading commentators such as Aschauer et al have extensively examined hybrid finance, thin capitalisation rules are specifically excluded from the scope of their paper: Aschauer et al, above n 6, 115-133.

${ }^{8}$ Klostermann, above n 6.

9 Dharmapala D, 'What Do We Know About Base Erosion and Profit Shifting? A Review of the Empirical Literature' (Illinois Public Law Research Paper No 14-23, 15 June 2014).

${ }^{10}$ Lohse T and Riedel N, 'Do Transfer Pricing Laws Limit International Income Shifting? Evidence from European Multinationals' (CESifo Working Paper No 4404, September 2012).

${ }^{11}$ Burnett C, 'Intra-Group Debt at the Crossroads: Stand-Alone versus Worldwide Approach' (2014) 6(1) World Tax Journal (27 January 2014).

${ }^{12}$ Traversa E, 'Interest Deductibility and the BEPS Action Plan: nihil novi sub sole?' [2013] 5 British Tax Review 607.

${ }^{13}$ The Public Discussion Draft was released on 18 December 2014, with the Public Consultation meeting scheduled for 17 February 2015: see OECD, Public Discussion Draft, BEPS Action 4: Interest deductions and other financial payments, 18 December 2014 - 6 February 2015, available at: http://www.oecd.org/ctp/aggressive/discussion-draft-action-4-interestdeductions.pdf; see further: Blouin J, Huizinga H, Laeven L and Nicodème G, Thin capitalisation rules and corporate leverage (29 March 2014) Vox EU; available at: http://www.voxeu.org/article/thin-capitalisation-rules-and-corporateleverage.

${ }^{14}$ OECD, Report on "Thin Capitalisation" (OECD 1986), adopted by the OECD Committee on Fiscal Affairs on 26 November 1986 (the 'Thin Capitalisation Report'); Similarly, the OECD's survey of thin capitalisation regimes currently remains in draft form only, with no indication of when it will be finalised: OECD, Thin capitalisation legislation a background paper for country tax administrations, draft paper, available at: http://www.oecd.org/ctp/taxglobal/5.\%20Thin_Capitalization_Background.pdf.

${ }^{15}$ Traversa, above $\mathrm{n} 12$. 


\subsection{Practice - and Issues in Practice}

To assess the effectiveness of thin capitalisation rules it is necessary to examine these rules in both theory and practice. This paper will focus in particular on issues in practice; specifically, balancing competing policy objectives and weaknesses in legal design.

\subsubsection{Departures from good tax design}

Over the past two decades, innovations to cross-border financing by MNEs has challenged the traditional financial and legal distinctions between debt and equity, putting into question the robustness of the international tax system, including the thin capitalisation framework. Each jurisdiction's aspiration to protect their own national tax base from debt shifting by MNEs is the raison d'être of thin capitalisation rules. For example, Australia's explanatory materials to its thin capitalisation legislation clearly state these rules are in place "to prevent the excessive allocation of debt for tax purposes". ${ }^{16}$

Australia's thin capitalisation rules aim to balance three-fold tax policy considerations in setting the relevant debt limits, specifically: ${ }^{17}$ first, "minimising unnecessary compliance costs for multinationals" (simplicity and transparency); second, "ensuring that the debt limits do not impede the efficient allocation of capital" (efficiency); and third, "maintaining the integrity of the revenue base" (sustainability). However, the artificial caps and ratios that typify thin capitalisation rules arguably conflict with both simplicity and efficiency concerns. ${ }^{18}$ The latter is the focus of this paper because unlike departures from simplicity, which adversely affect compliance and administrative costs, "departures from neutrality ... are some of the principal building blocks which so-called 'tax planners' use to erect schemes of (legal) tax avoidance, often of a highly artificial kind". ${ }^{19}$

\subsection{Efficiency}

The economic efficiency benchmark criteria for company taxation is synthesised by leading academic Warren, as shown in Figure 2 below. ${ }^{20}$

\footnotetext{
${ }^{16}$ Explanatory Memorandum, Tax and Superannuation Laws Amendment (2014 Measures No 4) Bill 2014 (Cth), 4.

${ }_{18}^{17}$ Explanatory Memorandum, above n 16, 4.

${ }^{18}$ Webber S, 'Thin Capitalization and Interest Deduction Rules: A Worldwide Survey' Tax Notes International: Special Report (29 November 2010) 683, 703.

19 At the centre of public finance analysis is the topic of distortions introduced (and corrected) by taxation. Tax-induced reductions in economic efficiency are known as deadweight losses or excess burdens of taxation, signifying the cost to taxpayers and society of raising revenue through taxes that distort economic decision. The tax neutrality principle states that tax systems should strive to be neutral such that decisions are made on their economic merits, rather than for tax reasons. "Departures from neutrality, whether in the form of concessions or lack of alignment between different taxes, are some of the principal building blocks which so-called 'tax planners' use to erect schemes of (legal) tax avoidance, often of a highly artificial kind ... The opportunities for practices of this kind are of concern not only because they do damage to the equity of the system, and the attitudes of other taxpayers to compliance with it, in that certain taxpayers (more predominantly the relatively well-to-do ones) reduce their tax relative to others" Taxation Reforms: Problems and Aims, Treasury Taxation Paper No 1, 1974; see further, Auerbach AJ and Hines JR, 'Taxation and Economic Efficiency' (NBER Working Paper No 8181, National Bureau of Economic Research, March 2001).

${ }^{20}$ Warren NA (eds), 'Modelling the economic outcomes from TVM: is it practical and meaningful', in Tax Value Method Consultative Conference (presented at Tax Value Method Consultative Conference, Coogee Beach, Sydney, 23-24 July 2001), 197-215.
} 
Figure 2

\begin{tabular}{|c|c|c|}
\hline \multicolumn{3}{|c|}{ Economic Efficiency } \\
\hline & eria & Description \\
\hline 1 & Funding neutrality & Do not distort the decision on how to fund a business (eg debt vs equity) \\
\hline 2 & Risk neutrality & Permits risk offset and adjustment \\
\hline 3 & Business structure neutrality & Incorporated and unincorporated companies treated similarly \\
\hline 4 & Net Income neutrality & $\begin{array}{l}\text { Neutral in its treatment of different income and expenditure sources and asset and } \\
\text { liability types }\end{array}$ \\
\hline 5 & Payout neutrality & $\begin{array}{l}\text { Neutral between dividends and retentions; and } \\
\text { neutral in its impact on financial innovation (bifurcation vs aggregation) }\end{array}$ \\
\hline 6 & Taxpayer neutrality & $\begin{array}{l}\text { Incentives to different groups should result in the same outcome for individuals } \\
\text { whatever structure is invested in }\end{array}$ \\
\hline 7 & Capital import/export neutrality & Benefit to resident and offshore investors should be similar. \\
\hline 8 & Institutional neutrality & $\begin{array}{l}\text { No prejudice or favour by government to sectors or groups (and if so, any market } \\
\text { intervention should be efficiently targeted, transparent and costed). }\end{array}$ \\
\hline
\end{tabular}

Regarding the neutrality of cross-border capital income taxation, the theoretical literature predominantly focusses on capital import neutrality ('CIN') ${ }^{21}$ capital export neutrality ('CEN') ${ }^{22}$ and capital ownership neutrality ('CON'). ${ }^{23}$ However, these neutrality benchmarks have received substantial criticism in the literature. Notably, leading commentators such as Graetz, Shaviro, and Grubert and Altshuler posit that none of these benchmarks are satisfactory because the arguments supporting them usually take place within very simple models. ${ }^{24}$ Some commentators argue that neutrality should evolve beyond the CEN and CIN debate to instead focus on global optimality and production efficiency. ${ }^{25}$

Despite the prevalence of commentators such as Shaheen ${ }^{26}$ detailing international tax neutrality considerations, the literature remains largely silent on the absence of funding neutrality in the design of thin capitalisation rules. There is no compelling reason why debt should be actively tax-favoured. Although thin capitalisation rules deny 'excessive' interest deductions, they are essentially ad hoc,

\footnotetext{
${ }^{21}$ Capital import neutrality requires that domestic and foreign investors receive the same after-tax rate of return on similar investments in that market. It aims for neutrality in international savings decisions and is embodied in a territorial or sourcebased tax system; see further, Gravelle JG, 'Reform of U.S. International Taxation: Alternatives' (Congressional Research Service, Report No. RL34115, 27 December 2012), 5.

${ }^{22}$ Capital export neutrality requires that investors in a country are subject to the same effective tax rate on income from domestic investment and income from foreign investment, such that the allocation of investments between countries is unaffected by tax considerations. It is embodied in a residence-based tax system; see further, Gravelle, above n 21, 5 .

${ }^{23}$ Capital ownership neutrality requires that countries not tax the offshore investments of resident companies, focussing instead on taxing domestic source income tax systems. It is neutral towards asset ownership on a worldwide basis and achieving it would be consistent with CIN; see further, Desai MA and Hines JR, 'Evaluating International Tax Reform' (2003) 56(3) National Tax Journal 487.

${ }^{24}$ Grubert and Altshuler, above n 1, 320 and 331-333; see further, Graetz MJ, 'Taxing International Income: Inadequate Principles, Outdated Concepts, and Unsatisfactory Policies' (2001) 54 Tax Law Review 261, 280-282 [observing that increasing worldwide welfare does not necessarily increase national welfare in the case of international tax policy, thereby supporting national welfare, rather than worldwide efficiency, as a policy goal]; Shaviro D, "Why Worldwide Welfare as a Normative Standard in U.S. Tax Policy?' (2007) 60 Tax Law Review 155, 164-65 [contending that, even if worldwide welfare improves national welfare by encouraging cooperative behaviour, unobserved defections should improve national welfare].

${ }^{25}$ Devereux MP, 'Taxation of Outbound Direct Investment: Economic Principles and Tax Policy Considerations' (Oxford University Centre for Business Taxation Working Papers No 02/24, September 2008); Diamond and Mirrlees' production efficiency theorem provides a rationale for a neutral tax system. This theorem states that, in a competitive economy, an optimal tax structure is characterised by production efficiency so long as all economic activities, and any pure profits, can be taxed. Importantly, production efficiency cannot be achieved by residence- or source-based taxes unless they are fully harmonized because the Diamond and Mirrlees theorem was derived for a closed economy with a single government budget constraint, see further: Nicodème GJA, 'Corporate Income Tax and Economic Distortions' (CESifo Working Paper Series No 2477, CESifo Group Munich, 2008). However, in the absence of international agreement, the question then is which system (source-based or residence-based) generates greater welfare costs. However, leading commentators observe that decisions of location involve the choice between cross-border investment and trade so any argument in favour of one form of taxation on this basis would be precarious, see further: Devereux, above $\mathrm{n} 25,17$.

${ }^{26}$ Shaheen F, 'International Tax Neutrality: Reconsiderations' (2007) 27 Virginia Tax Review 203.
} 
and fail to capture all avoidance-related transactions or acknowledge the differing debt capacities of different companies. ${ }^{27}$

It is arguably counter-intuitive for thin capitalisation rules, particularly since they are purportedly anti-avoidance rules dealing with firms' funding decisions, to not further prioritise neutrality. A recent paper by Massimi and Petroni, cited by the European Commission, went as far as to say that "neutrality with regard to firms' funding decisions makes theoretically redundant the adoption of thin capitalisation rules" ${ }^{28}$

Even though thin capitalisation rules are generally characterised as part of the anti-avoidance framework, this view is also questionable because thin capitalisation rules are "not targeted antiabuse rules' but structural changes intended to mitigate the effects of the deduction for interest on debt". ${ }^{29}$ Leading commentators such as Burnett ${ }^{30}$ and Brown ${ }^{31}$ observe it is unfortunate that these rules are characterised as anti-abuse rules, highlighting that the legal basis for thin capitalisation rules does not reconcile with the economic basis.

While it is arguable that even if thin capitalisation rules were re-designed to attain funding neutrality, attaining full neutrality ${ }^{32}$ between debt and equity is nearly impossible without full international tax coordination. ${ }^{33}$ Nonetheless, MNEs financing and investment decisions will always be responsive to the tax environment to the extent that they will engage in alternative means of minimising their tax liabilities ${ }^{34}$ so a 'second-best solution' ought to be devised that attains as many of the good tax design criteria as practicable. Accordingly, the following section will consider funding neutrality in further detail.

\subsection{Mitigating the debt bias}

Most leading commentators and policymakers assume that thin capitalisation rules mitigate the debt bias, with the literature containing a plethora of statements such as: "Other methods of addressing debt bias ... [include implementing] stronger thin capitalization rules"; "The Member States that did broaden their corporate tax base mostly focused on limiting interest deductibility to reduce the debt bias", ${ }^{36}$ "Our results indicate that thin capitalization rules mitigate the sensitivity of affiliate leverage

\footnotetext{
${ }^{27}$ Fiscal Affairs Department, 'Debt Bias and Other Distortions: Crisis-Related Issues in Tax Policy', International Monetary Fund, 12 June 2009, 13.

${ }^{28}$ Massimi F and Petroni C, 'Real-World ACE Reforms and the Italian Experience. Towards a General Trend?' (2012) 40(11) Intertax 632.

${ }^{29}$ Brown P, General Report: The Debt-Equity Conundrum, 97b Cahiers de Droit Fiscal International (2012), 40-41.

${ }^{30}$ Burnett, above $\mathrm{n} 11,45$.

${ }^{31}$ Brown, above $\mathrm{n} 29$.

${ }^{32}$ The tax neutrality principle states that tax systems should strive to be neutral such that decisions are made on their business or economic merits, rather than for tax reasons.

${ }^{33}$ Butler KC, Multinational Finance (USA: Thomson, $3^{\text {rd }}$ ed, 2004), 440; In a real-world situation in which there are crossborder flows of portfolio and direct investment, and also international trade, then all traditional forms of taxation would be distorting to some extent unless they were completely harmonised: see further, Diamond PA and Mirrlees JA, 'Optimal Taxation and Public Production I: Production Efficiency' (1971) 61(1) The American Economic Review 8; Devereux, above $\mathrm{n} 25$; further, full neutrality between debt and equity would also require dividends, capital gains and interest payment being taxed at the same rate at the individual shareholder level: see further, Gammie M, "Corporate tax harmonization: an "ACE" proposal: harmonizing European corporate taxation through an allowance for corporate equity' (1991) 31(8) European Taxation Journal 238.

${ }^{34}$ Mintz J and Smart M, 'Income shifting, investment, and tax competition: theory and evidence from provincial taxation in Canada' (2004) 88 Journal of Public Economics 1149; Weichenrieder AJ and Windishbauer H 'Thin capitalization rules and company responses' (CESifo Working Paper No 2456, November 2008); Buettner T and Wamser G, 'Internal Debt and Multinationals' Profit Shifting: Empirical Evidence form Firm-level Panel Data' (Working Paper 0918, Oxford University Centre for Business Taxation, 2009); Schindler D and Schjelderup G, 'Transfer Pricing and Debt Shifting in Multinationals' (CESifo Working Paper Series No 4381, August 2013).

${ }^{35}$ Shaviro DN, 'Income Tax Reform Implications of the Financial Crisis', Chapter 7 in: Taxation and the Financial Crisis, edited by Alworth JS and Arachi G (UK: Oxford University Press, 2012), 180.

${ }^{36}$ European Commission, 'Tax reforms in EU member states 2013: Tax policy challenges for economic growth and fiscal sustainability: 2013 Report', European Economy 5 (Brussels: European Commission, DG ECFIN and DG TAXUD, October 2013), 22.
} 
ratios to corporate taxation"; "Several policy options are available which could limit the tax bias towards debt financing ... [one] option is to implement thin capitalization rules"; 38 "[debt] bias is reduced by the interest deduction limitation rules"; 39 and, "Many countries have attempted to offset this debt bias ... by imposing thin capitalization rules", ${ }^{40}$ to cite just a few.

The empirical evidence supports the proposition that thin capitalisation rules do impact MNEs financing decisions. Buettner et al, ${ }^{41}$ a leading study on thin capitalisation rules worldwide, ${ }^{42}$ find that the imposition of thin capitalisation rules results in a decline in internal debt-to-asset ratios. Despite acknowledging that the magnitude of internal debt shifting is relatively small, they finding that when thin capitalisation rules are introduced or tightened, the tax sensitivity of the internal debt ratio falls by about a half. ${ }^{43}$ Other empirical studies suggest that the debt-to-asset ratio is marginally tax sensitive, simulation results suggesting a $2.8-3.5 \%$ increase in internal debt-to-asset ratios following a $10 \%$ increase in the corporate tax rate. ${ }^{44}$ Ruf and Schindler highlight the econometric difficulties in consistently recording and identifying the impact of thin capitalisation rules. ${ }^{45}$ This is strongly supported by Grubert and Altshuler, who observe that from an empirical analysis perspective, the models and estimates of behavioural elasticities required for judging an international corporate tax system definitively are beyond the scope of current knowledge. ${ }^{46}$ It is also noteworthy that the existing literature typically captures the tax advantages of debt by exclusively using information on tax rates, rather than considering other differences in tax codes that constrain leverage and thus the value of tax shields. ${ }^{47}$ So, even though there is extensive literature on neutrality principles, each proposed standard is based on simplifying assumptions. ${ }^{48}$

Importantly, empirical results suggest that thin capitalisation rules are effective anti-avoidance provisions. However, some leading commentators suggest that rather than mitigating the debt bias, thin capitalisation rules simply encourage levels of debt at the specified threshold debt-equity ratios. It is plausible that MNEs are technically complying with thin capitalisation rules by gearing at the specified threshold levels, then utilising other means such as hybrid finance to bypass these rules. However, these legal design issues are not presently included in empirical analysis.

While there is an extensive and growing literature across a number of disciplines that analyses corporate tax avoidance, ${ }^{49}$ leading academics such as Dharmapala observe that there is very little literature that directly studies the process and structure of corporate tax planning, ${ }^{50}$ with the exception of Mills et al. ${ }^{51}$ This signals a gap in the literature on the question of whether or not MNEs generally operate at or near the current legal limits.

The following hypothetical scenario demonstrates the impact of tightening thin capitalisation rules on an MNE which is operating at the legal limits of the Australian thin capitalisation regime. The base figures are derived from the most relevant examples provided by the ATO, as contained in Taxation

\footnotetext{
${ }^{37}$ Blouin J, Huizinga H, Laeven L and G Nicodème, 'Thin capitalization rules and multinational firm capital structure' (Oxford University Centre for Business Taxation Working Paper WP 13/23, November 2013), 27 - it is noteworthy that this statement was removed from an updated version of the same paper published two months later in: Blouin et al, above $\mathrm{n} 4$.

${ }^{38}$ Fatica S, Hemmelgarn T and Nicodème G, 'The Debt-Equity Tax Bias: consequences and solution' (Taxation Papers Working Paper No 33, European Commission, July 2012), 11.

${ }^{39}$ Bundgaard J and Tell M, 'Tax neutrality and corporate financing' (2010) 1 European Tax Studies, 20.

${ }^{40}$ World Bank, Lessons of Tax Reform: An Overview, edited by Thirsk W (Washington DC: World Bank Publications, 1991), 11.

${ }^{41}$ Buettner et al, above $\mathrm{n} 62$.

${ }^{42}$ Ruf and Schindler, above $n 57$.

${ }^{43}$ Buettner et al, above $\mathrm{n} 62$.

${ }^{44}$ Desai, above n 75; Ruf and Schindler, above n 57, and footnotes cited therein.

${ }^{45}$ Ruf and Schindler, above $\mathrm{n} 57,10$.

${ }^{46}$ Grubert and Altshuler, above n 1, 319-321.

${ }^{47}$ Blouin et al, above $\mathrm{n} 4,3$.

${ }^{48}$ Grubert and Altshuler, above n 1, 319 .

49 For instance, for an analysis of analysis of the impact of corporate governance and executive compensation on tax avoidance activity see: Desai MA and Dharmapala D, 'Taxation and Corporate Governance: An Economic Approach' in: Schön W (ed.) Tax and Corporate Governance (Berlin, Germany: Springer Berlin-Heidelberg, 2008), 13-30.

${ }^{50}$ Dharmapala, above $\mathrm{n} 9$.

${ }^{51}$ See Mills L, Erickson M, Maydew E, 'Investments in Tax Planning' (1998) 20(1) The Journal of the American Taxation Association 1-20.
} 
Ruling TR2010/7. In relation to the inter-company loan shown in Figure 3 below, the thin capitalisation rules permitted a 3:1 gearing ratio (assuming an arm's length rate of $12 \%$, thereby allowing $\$ 36,000,000$ in annual debt deductions $)^{52}$ until they were recently amended by the Tax and Superannuation Laws Amendment (2014 Measures No 4) Act 2014 (Cth) to a 1.5:1 gearing ratio.

Figure 3

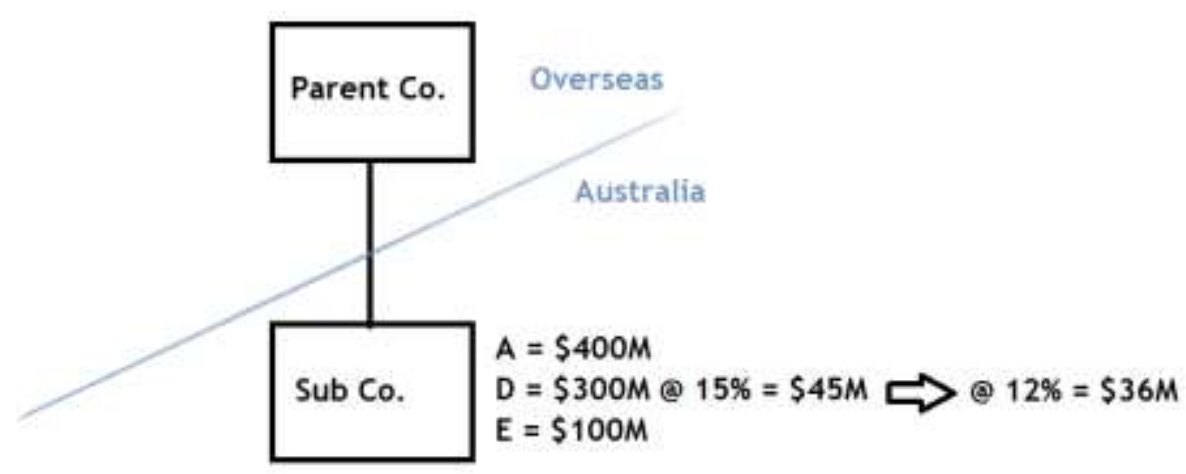

Key: $\mathrm{A}=$ assets, $\mathrm{D}=$ debt, $\mathrm{E}=$ equity, $15 \%=$ intercompany interest rate, $12 \%=$ arm's length rate.

This presents a conflict that is a legitimate struggle from a policy perspective. Namely, if a foreign company first goes out of its way to undercapitalise its Australian operations (for example at materially less than a 3:1 gearing ratio), and then lends money to that subsidiary at junk bond (albeit arm's length) interest rates, this would effectively allow more debt deductions, while presenting a loss of potential FDI flows and a potentially higher risk of bankruptcy. ${ }^{53}$

The recent move to a 1.5:1 gearing ratio, even though it was proposed for revenue reasons, arguably encourages a more equal balance of debt and equity finance. However, this paper submits that regulatory changes reducing the allowable debt to equity ratio should not be conflated with attaining funding neutrality. This is demonstrated by Figure 4, whereby the Australian subsidiary has the option of simply halving debt levels from $\$ 300,000,000$ to $\$ 150,000,000$. This has the implication of reducing its FDI flows into Australia. ${ }^{54}$

\footnotetext{
${ }^{52}$ Australian Taxation Office, Income tax: the interaction of Division 820 of the Income Tax Assessment Act 1997 and the transfer pricing provisions (27 October 2010) ATO Taxation Ruling TR2010/7, available at: http://law.ato.gov.au/atolaw/view.htm?DocID=TXR/TR20107/NAT/ATO/00001. See, Example 1: Australian thin capitalisation rules currently provide a 3:1 debt to equity safe harbour for general inbound and outbound investment. An Australian subsidiary of a foreign parent has $\$ 400,000,000$ assets, $\$ 100,000,000$ share capital and $\$ 300,000,000$ loans at $15 \%$ interest from its parent. On this basis, it has satisfied the safe harbour ratio of the thin capitalisation rules and claims $\$ 45,000,000$ in annual debt deductions. Assuming that the maximum amount that the subsidiary could borrow on arm's length terms in the open market was $\$ 190,000,000$ with an interest rate of $12 \%$, the subsidiary would only be able to deduct $\$ 36,000,000$, being interest at $12 \%$ on the $\$ 300,000,000$ of actual debt which is at the safe harbour limit. Further, the ATO rejects the view that it must accept the safe harbour amount as in effect a deemed arm's length amount of debt and then carry out the transfer pricing analysis of the interest rate on that basis.

${ }^{53}$ Greenwoods \& Freehills, 'Tax Brief: Transfer pricing and thin capitalisation', 23 December 2009, available at: http://www.gf.com.au/Transfer_pricing_and_thin_capitalisation.pdf.

${ }^{54}$ The link between tightening debt deductions through thin capitalisation rules and reduced investment has been established by Buettner et al, “... tax policy should take account of the adverse investment effects of restrictions on tax planning by means of debt finance. Imposing restrictions alone does not enable tax policy to escape the fundamental questions concerning the corporation tax realised by the emergence of multinationals": Buettner et al, above n 62, 32 .
} 


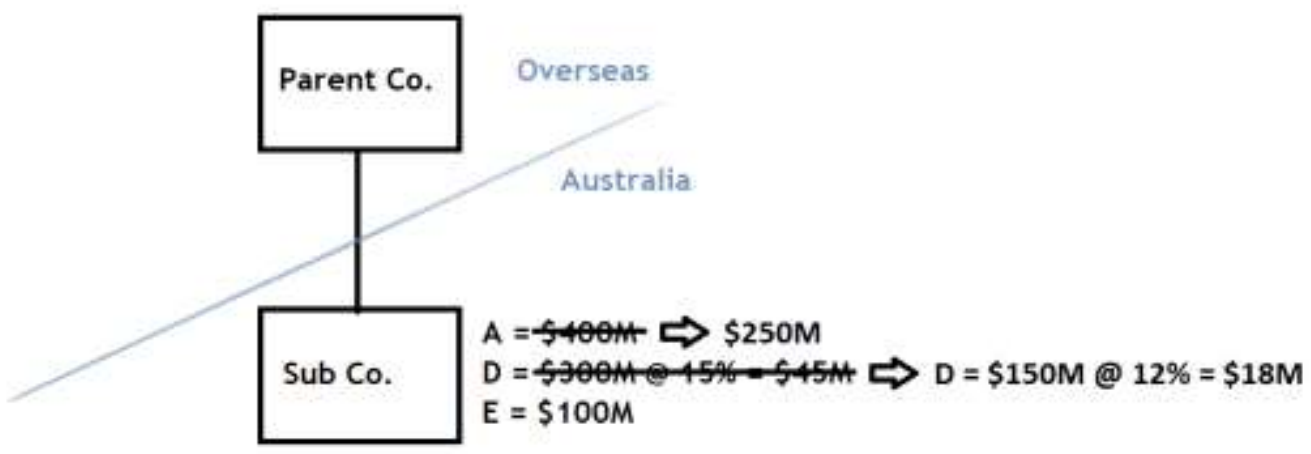

Further, Ruf and Schindler posit that the empirical evidence merely supports the proposition that, for the average MNE, there is no need to implement thin capitalisation rules because of their nominal impact. ${ }^{55}$ They observe that the mismatch between anecdotal evidence provided by tax consultants and auditors, and the relatively weak empirical evidence concerning all MNEs is attributable to the fact that most MNEs do not engage in international debt shifting. Rather, they believe that only a few large MNEs engage in aggressive tax planning and that thin capitalisation rules cause significant collateral damage by requiring non tax-aggressive MNEs to bear the administrative burden of these complex rules. ${ }^{56}$

To the best of this author's knowledge, this evidence remains anecdotal, indicating a research need for empirical studies confirming this proposition. Research in this area is also lacking surveys or interviews with accounting and law firm partners, and private equity firm managers, which could be the subject of future research.

\subsubsection{Legal design weaknesses}

Legal analysis of thin capitalisation rules is usually limited to commentators analysing a single point in time and from the perspective of one jurisdiction only, despite the exponentially increasing implementation of, and extensive commentary on, these rules. The tax design of thin capitalisation rules $^{57}$ remains understudied in the corporate finance literature, despite criticism from leading commentators; notably, de Mooij: ${ }^{58}$

"Several countries have introduced measures that put a cap on interest deductibility, often called thin capitalization rules or income stripping rules. They seem to have reduced debt ratios-most likely through adjusting the levels of intra-company debt to which many of these rules apply. Yet, they also seem to have reduced investment. Moreover, these rules are only imperfect solutions to the problem of debt bias and come along with other costs. In fact, they are usually ad-hoc, not well targeted, and are often avoided by firms that can exploit hybrid instruments and international differences in definitions of debt and equity. Closing loopholes generally leads to refinements and complexities of tax laws"

Accordingly, the following sections highlight three key legal design issues; first, the ad hoc nature of thin capitalisation rules; second, their complexity; and third, the tax arbitrage opportunities they encourage.

\footnotetext{
${ }^{55}$ Ruf M and Schindler D, 'Debt Shifting and Thin-Capitalization Rules - German Experience and Alternative Approaches' (NHH Discussion Paper, RRR 06-2012, 13 December 2012), 9.

${ }_{56}$ Ruf and Schindler, above n 55, 9-10.

${ }^{57}$ Ruf and Schindler, above n 55; Arnold, above n 5; Piltz, above n 5; Dourado and and de la Feria, above n 3.

${ }^{58}$ Ruud de Mooij, Fiscal Affairs Department, UK Parliamentary Commission for Banking Standards, Written evidence submitted by the International Monetary Fund, 24 June 2013, 502.
} 


\subsection{Ad hoc application}

Thin capitalisation rules are generally ad hoc from both a domestic perspective and also an international consistency perspective.

Domestically, existing debt-to-equity ratios are blunt rules that are neither industry nor entity specific. It is therefore questionable that they can be considered suitable proxies for ascertaining whether the borrowing company is truly geared with the motivation of engaging in debt shifting. Remarkably, thin capitalisation rules assume that it is possible to estimate these ratios for all companies within all industries in the one jurisdiction. ${ }^{59}$ In reality, customising thin capitalisation rules to specific industries and deciding on appropriate industry-specific ratios would be nearly impossible. Even if this were administratively feasible, it would also be difficult to assign firms to specific industries if they operated across multiple industries. ${ }^{60}$ Further, leverage ratios are likely to be a function of size, complexity and international operations of the MNE.

Internationally, no two countries have identical thin capitalisation rules. Further, interest limitation regimes appear to be rather unstable - most countries have rewritten theirs at least once. Despite the variability, most countries' rules sit somewhere along a spectrum which has at one end a stand-alone entity approach, and at the other end a worldwide ratio approach. Leading commentators such as Burnett question the appropriateness of a single arm's length leverage ratio or interest rate for a given subsidiary, or even a workable range of ratios and rates. ${ }^{61}$ Even though empirical evidence supports the proposition that thin capitalisation rules technically restrict internal borrowing by $\mathrm{MNCs},{ }^{62}$ it is relatively simple for MNEs to circumvent these rules. For example, entities falling outside the threshold levels are openly advised to reassess their thin capitalisation positions by either: reducing debt; re-valuing assets; or, re-capitalising to prevent the denial of interest expenditure. ${ }^{63}$ Accordingly, thin capitalisation rules are arbitrary, ad hoc provisions that fail to effectively target avoidance-related transactions. ${ }^{64}$

\subsection{Complicated framework}

It goes without saying that the problem of profit shifting will not, and cannot, be completely solved by introducing anti-abuse rules, be it through domestic legislation or international tax treaties. ${ }^{65}$ Rather, the key challenge is in striking an appropriate balance of policy considerations in devising robust antiavoidance rules that adequately protect the tax base without imposing excessive compliance costs or hampering normal business operations of MNEs. ${ }^{66}$

For instance, in addition to Australia's thin capitalisation rules, there is a wider international tax framework including but not limited to complex debt and equity rules; dividend imputation and corporate shareholder taxation issues $;{ }^{67}$ withholding taxes $;{ }^{68}$ other jurisdictions' thin capitalisation

\footnotetext{
${ }^{59}$ Burnett, above $\mathrm{n} 11$.

${ }^{60}$ Farrar J and Mawani A, 'Debt-Equity Limitations in Thin Capitalization Rules: Canadian Evidence' (Paper presented at CAAA 2008 Annual Conference, 4 January 2008).

${ }^{61}$ Burnett, above $\mathrm{n} 11$.

62 Overesch M and Wamser G, 'Bilateral internal debt financing and tax planning of multinational firms' (2014) 42(2) Review of Quantitative Finance and Accounting 191.; Buettner T, Overesch M, Schreiber U and Wamser G, 'The Impact of Thin-Capitalization Rules on the Capital Structure of Multinational Firms' (2012) 96 Journal of Public Economics, 930-938; Ruf M and Schindler D, 'Debt Shifting and Thin-Capitalization Rules - German Experience and Alternative Approaches' (NHH Discussion Paper, RRR 06-2012, 13 December 2012).

${ }^{63} \mathrm{PwC}$, 'Tighter thin capitalisation regime to limit Australian debt deductions' (26 September 2013), available at: http://www.pwc.com.au/tax/federal-budget/2013/thin-capitalisation.htm.

${ }^{64}$ Fiscal Affairs Department, above n 27, 13.

${ }^{65}$ Traversa, above n 12.

${ }^{66}$ OECD, Hybrid Mismatch Arrangements: Tax Policy and Compliance Issues (Paris: OECD Publishing, March 2012).

${ }^{67}$ See further Taylor CJ, 'Approximating Capital-Export Neutrality in Imputation Systems: Proposal for a Limited Exemption Approach' (2003) 57 Bulletin for International Taxation 135; Taylor CJ, 'Development of and Prospects for Corporate-Shareholder Taxation in Australia' (2003) 57 Bulletin for International Taxation 346.

${ }^{68}$ Importantly, the Henry Review criticised Australia's current treatment of foreign debt as complex and distortionary, recommending a reduction in the interest withholding tax rate to zero among tax treaty partners. With an effective interest
} 
rules; bilateral tax treaties; the interactions with the OECD Model Tax Convention, including Articles 9(1) and 24(4); OECD Guidelines; and other OECD materials. For completeness, there is also a close connection between anti-abuse rules concerning excessive interest and CFC rules. ${ }^{69}$ Australia's existing thin capitalisation regime contained in Division 820 of the ITAA 1997 currently spans over 150 pages of legislation, ${ }^{70}$ with highly technical rules requiring complicated calculations. There is a strong consensus in the literature that the existing thin capitalisation framework is highly technical and complicated.

This calls into question whether the thin capitalisation rules achieve simplicity and transparency. The literature also questions whether the existing legal design of these rules conflicts with the effectiveness and fairness principles. ${ }^{71}$

\subsection{Tax arbitrage opportunities}

The literature also recognises that thin capitalisation rules may be avoided by MNEs that can exploit tax arbitrage opportunities; namely, hybrid financial instruments and international differences in definitions of debt and equity. ${ }^{72}$ Despite the literature acknowledging these issues, ${ }^{73}$ very few empirical papers examine this aspect. ${ }^{74}$ Instead, the literature analysing thin capitalisation rules focusses on their impact on intercompany loans, and it generally limited to datasets from the United States ${ }^{75}$ and the EU. ${ }^{76}$

Further, the finance literature often identifies the tax deductibility of debt as the most significant factor governing the choice between third-party debt and equity finance. However, from an economic substance perspective, the reasons put forward to distinguish third-party debt from equity generally do not hold in an intra-group situation. Also, empirical findings suggest that intra-group debt and thirdparty debt are substitutable. ${ }^{77}$ This warrants challenging the need for, and utility of, Australia's debt and equity rules ${ }^{78}$ in the context of the thin capitalisation rules. ${ }^{79}$ This provides the basis for further

withholding tax rate of $3.5 \%$, liability for withholding tax would likely not outweigh the advantages of interest deductibility given comparative levels of corporate tax. While the literature has recognised the debt bias as prevalent in the foreign debt context, leading policy makers have called for the reduction of interest withholding tax to $0 \%$ provided appropriate safeguards exist to limit tax avoidance: "Recommendation 34: Consideration should be given to negotiating, in future tax treaties or amendments to treaties, a reduction in interest withholding tax to zero so long as there are appropriate safeguards to limit tax avoidance"; Henry K, Harmer J, Piggott J, Ridout H and Smith G, Australia's Future Tax System: Report to the Treasurer, Commonwealth of Australia, December 2009, Part 2, Chapter B1-4 ('Henry Review'), available at: http://taxreview.treasury.gov.au/content/FinalReport.aspx?doc=html/publications/Papers/Final_Report_Part_2/chapter_b1 4.htm.

${ }^{69}$ OECD, above $\mathrm{n} 147,17$ and 31. For an analysis of the effectiveness of CFC provisions, see Ruf M and Weichenrieder AJ, 'The Taxation of Passive Foreign Investment: Lessons from German Experience' (CESifo Working Papers No 2624, April 2009).

${ }^{70}$ Income Tax Assessment Act 1997 (Cth).

${ }^{71}$ Webber, above n 18.

${ }^{72}$ By way of background, the difference between debt and equity stems from the legal, finance and accounting realms, rather than being grounded in tax or economic principles. Unlike finance, neither tax nor economics is concerned with the function of debt as a safeguard for third party liabilities. Accordingly, the non-neutrality in the tax treatment between debt and equity finance (in other words, the tax-induced debt bias) is distortive from a tax perspective, creates complexity, encourages avoidance, and adds unnecessary administrative and compliance costs for both MNEs and governments. These issues are exacerbated in the context of cross-border hybrids: OECD, Public Discussion Draft, BEPS Action 2: Neutralise the Effects of Hybrid Mismatch Arrangements (Recommendations for Domestic Laws), 19 March 2014 - 2 May 2014, available at: http://www.oecd.org/ctp/aggressive/hybrid-mismatch-arrangements-discussion-draft-domestic-laws-recommendationsmarch-2014.pdf.

${ }_{73}^{73}$ De Mooij RA and Keen MJ, 'Debt, Taxes and Banks' (IMF Working Paper 12/48, February 2012).

74 The only detailed discussion of the treatment of hybrid finance under thin capitalisation rules appears to be in Klostermann, above $\mathrm{n} 6$.

${ }^{75}$ Data was used from the US Bureau of Economic Analysis: Desai M, Foley CF and Hines JR, 'The Costs of Shared Ownership: Evidence from International Joint Ventures' (2004) 73(2) Journal of Financial Economics 323.

${ }^{76}$ A large mirco-level panel dataset of virtually all German MNCs compiled by Deutsche Bundesbank, which included information about the actual amount of internal debt used by foreign affiliates, distinguished into loans from the parent and loans received from other foreign affiliates: Buettner T and Wamser G, 'Internal Debt and Multinational Profit Shifting: Empirical Evidence form Firm-level Panel Data' (2013) 66(1) National Tax Journal 63, 69.

${ }^{77}$ Burnett, above $\mathrm{n} 11$; see further studies cited therein.

${ }^{78}$ Division 974 of the Income Tax Assessment Act 1997 (Cth).

${ }^{79}$ Division 820 of the Income Tax Assessment Act 1997 (Cth). 
research by the author.

\section{FUNDAMENTAL REFORM: ADDRESSING THE CROSS-BORDER DEBT BIAS}

Thin capitalisation rules aim to prevent the erosion of the tax revenue base of a particular jurisdiction. However, the phenomenon of thin capitalisation arises from the decisions of revenue authorities to create a tax-induced cross-border debt bias, which presents opportunities for tax base erosion. ${ }^{80}$ Rather than introducing or tightening thin capitalisation legislation, which merely tackles the 'symptom' of debt shifting, it is arguably more effective to instead align the tax treatment of debt and equity financing to eliminate the tax incentive for thin capitalisation. This would address the underlying 'disease' of the debt bias.

It is important to not conflate successfully restricting debt deductibility with successfully attaining funding neutrality. Regardless of whether the amount of the debt deduction $\left(r^{\mathrm{D}}\right)$ is limited through the 'arm's length' approach or the 'ratio' approach, this is expressed as $\mathrm{r}^{\text {capped }} \%$ for ease of reference. On the other hand, equity deductions $\left(\mathrm{r}^{\mathrm{E}}\right)$ are denied, which can be expressed as a deduction of $0 \%$. Conceptualised in this way, limiting the deductibility of interest expenses through thin capitalisation rules may be misplaced in that such a limitation does not address the tax-induced cross-border debt bias (the underlying 'disease') by equalising the tax treatment of debt and equity financing. Rather, thin capitalisation rules merely target the behaviour of cross-border debt shifting (the 'symptom'). In other words, thin capitalisation rules mitigate the impact of the symptom yet neglect the impact of the disease, as shown in Table 1 below. This format will also be subsequently applied for each reform option considered in this paper.

\begin{tabular}{|l|l|}
\multicolumn{1}{c|}{ Table 1 } \\
\hline \multicolumn{1}{|c|}{} & $\begin{array}{l}\text { Thin } \\
\text { Capitalisation } \\
\text { Rules }\end{array}$ \\
\hline $\begin{array}{l}\text { Cost of debt } \\
\text { deductibility }\end{array}$ & $\mathrm{r}^{\mathrm{D}}=\mathrm{r}^{\text {cappedo } \%}$ \\
\hline $\begin{array}{l}\text { Cost of equity } \\
\text { deductibility }\end{array}$ & $\mathrm{r}^{\mathrm{E}}=0 \%$ \\
\hline $\begin{array}{l}\text { Impact on the } \\
\text { disease }\end{array}$ & Neglects \\
\hline $\begin{array}{l}\text { Impact on the } \\
\text { symptom }\end{array}$ & Mitigates \\
\hline
\end{tabular}

However, several fundamental reform options exist which would, in theory, eliminate the distinction between debt and equity in the corporate tax regime; either by disallowing deductions for the cost of debt financing, providing deductions for the cost of equity financing, or allowing deductions for the cost of both debt and equity financing.

Proposed fundamental reforms addressing each of these three options are the comprehensive business income tax ('CBIT'), the allowance for corporate equity ('ACE'), and the allowance for corporate capital ('ACC'), respectively. However, of these three reforms only the ACE has been experimented with in practice. Further, these fundamental reforms have only been conceptualised as reforms addressing the domestic-level debt bias. It is therefore instructive to consider reform proposals targeting the cross-border aspect, as shown in Table 2 below. ${ }^{81}$

\footnotetext{
${ }^{80}$ Hanlon D, 'Thin Capitalisation Legislation and the Australia/United States Double Tax Convention: Can They Work Together?' (2000) 3(1) Journal of Australian Taxation 4.

81 OECD, Fundamental Reform of Corporate Income Tax, Volume 16 of OECD Tax Policy Studies (Paris: OECD Publishing, 2007), 155.
} 
Table 2

Efficiency under fundamentally reformed corporate tax systems

\begin{tabular}{|c|c|c|c|c|c|c|c|c|c|c|}
\hline & \multicolumn{10}{|c|}{ Corperate tax-induced distortiensineutral corporate tax treatment } \\
\hline & \multirow[t]{2}{*}{$\begin{array}{l}\text { Corporate } \\
\text { levet: } \\
\text { domeste }\end{array}$} & \multirow[t]{2}{*}{$\begin{array}{l}\text { Corporate } \\
\text { ievet: inter- } \\
\text { national' }\end{array}$} & \multirow{2}{*}{$\begin{array}{c}\text { Capital gains } \\
\text { taxed upen } \\
\text { accrual }\end{array}$} & \multirow{2}{*}{$\begin{array}{c}\text { Capital gains } \\
\text { taxed upon } \\
\text { realisation } \\
\text { or at a lower } \\
\text { rate }\end{array}$} & \multirow{2}{*}{$\begin{array}{c}\text { Corperate } \\
\text { level: } \\
\text { domestic }\end{array}$} & \multirow[t]{2}{*}{$\begin{array}{l}\text { Corperate } \\
\text { levet: inter- } \\
\text { national' }\end{array}$} & \multirow{2}{*}{$\begin{array}{c}\text { Capitai gains } \\
\text { taxed upon } \\
\text { accrual }\end{array}$} & \multicolumn{2}{|c|}{$\begin{array}{c}\text { Capital gains taxed } \\
\text { upon realisation } \\
\text { of at a lover rate }\end{array}$} & \multirow[t]{2}{*}{$\begin{array}{c}\text { Tax } x \text { impact at } \\
\text { economic inflation on } \\
\text { seprociation depreciatior }\end{array}$} \\
\hline & & & & & & & & $\begin{array}{l}\text { Normal } \\
\text { retum }\end{array}$ & $\begin{array}{l}\text { Economic } \\
\text { rents }\end{array}$ & \\
\hline $\begin{array}{l}\text { CIT in most } \\
\text { ceuntries }\end{array}$ & D & D & D & 0 & $N$ & $n$ & $N$ & 0 & D & $p$ \\
\hline Full imputation & 0 & NO & N & 0 & $N$ & $n$ & N & 0 & D & P \\
\hline Sharehoider ACE & D & NDD & $N$ & $N$ & $N$ & $n$ & $N$ & $N$ & D & $n$ \\
\hline C8IT & $N$ & $N$ & $n$ & $N$ & $n$ & $n$ & $n$ & $n$ & $n$ & $P$ \\
\hline $\begin{array}{l}\text { Corporate } \\
\text { cash-flow }\end{array}$ & N & $N$ & N & D & N & $N$ & $n$ & 0 & D & N \\
\hline
\end{tabular}

$\mathrm{D}=$ distorted, $\mathrm{N}$ - neutrality, $\mathrm{P}$ - possibly neutral, PCrT = presumptive capital income tax.

1. Only the host country's corporate tax rate is considered

For completeness, although beyond the scope of Table 2, this paper will also examine the "combined ACE-CBIT" (a recently suggested hybrid of the ACE and the CBIT).

Consequently, the following sections consider the theoretical desirability and practical feasibility of the CBIT, the ACE, the ACC and the more recently proposed combined ACE-CBIT. This analysis is conducted with a view to examine in further research by the author whether, and if so how, the thin capitalisation rules could be replaced by one of these fundamental reforms.

\subsection{COMPREHENSIVE BUSINESS INCOME TAX}

The CBIT eliminates the debt bias by denying existing debt deductibility, thereby affording no tax deductions for either debt or equity financing. First proposed by the US Department of the Treasury, and more recently proposed by the IMF, ${ }^{82}$ the CBIT aims to end the classical double taxation of source income. ${ }^{83}$ It has its theoretical foundations in the fundamental equivalence between a corporate income tax levied at source and an equal-rate personal income tax on corporate earnings with full credit for the underlying corporate income tax.

Utilising the same inter-company loan scenario described earlier, Figure 5 below reflects no tax deduction being afforded to the Australian subsidiary.

\footnotetext{
${ }^{82}$ The IMF proposed a CBIT which denies interest deductibility for corporate income tax altogether while exempting interest received: IMF, 'A Fair and Substantial Contribution by the Financial Sector: Final Report for the G-20' (June 2010), available at: http://www.imf.org/external/np/g20/pdf/062710b.pdf.

${ }^{83}$ United States Government, Department of the Treasury, 'Report of the Department of the Treasury on Integration of the Individual and Corporate Tax Systems: Taxing Business Income Once’, January 1992.
} 


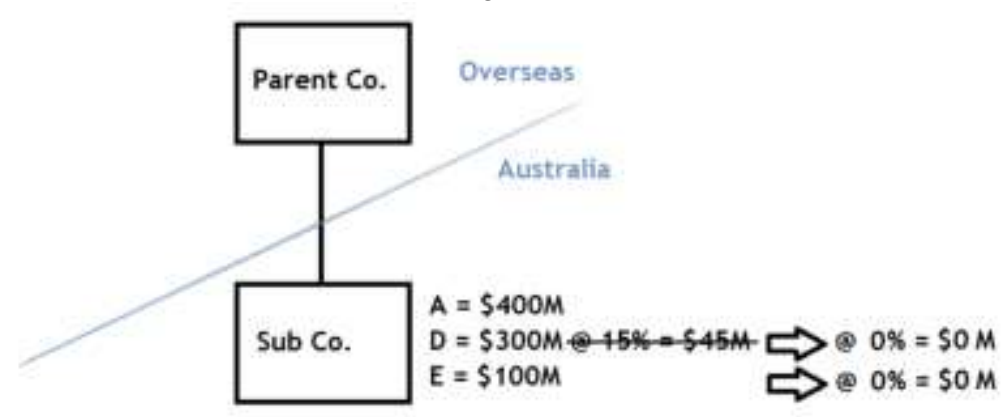

The CBIT equalises the tax treatment of debt and equity financing, by reducing the extent of deductibility to $0 \%$ (so, under this system $r^{D}=r^{E}=0 \%$ ). Accordingly, the CBIT would eliminate both the symptom of debt shifting and the underlying disease of the cross-border debt bias, thereby attaining funding neutrality. This is shown in Table 3 below.

\begin{tabular}{|l|l|}
\hline \multicolumn{2}{|c}{ Table 3} \\
\hline $\begin{array}{l}\text { Cost of debt } \\
\text { deductibility }\end{array}$ & $\mathrm{CBIT}$ \\
\hline $\begin{array}{l}\text { Cost of equity } \\
\text { deductibility }\end{array}$ & $\mathrm{r}^{\mathrm{E}}=0 \%$ \\
\hline $\begin{array}{l}\text { Impact on the } \\
\text { disease }\end{array}$ & Eliminates \\
\hline $\begin{array}{l}\text { Impact on the } \\
\text { symptom }\end{array}$ & Eliminates \\
\hline
\end{tabular}

While prima facie the CBIT achieves funding neutrality, it is important to take a balanced view with reference to both the advantages and disadvantages of the CBIT, with are subject to continuing debate in the literature. The key advantages, in addition to attaining funding neutrality, include the ability to implement a policy of tax-cut-cum-base-broadening, neutrality of organisational form, less vulnerability to international profit-shifting, potentially improving investment. The key disadvantages include introducing a distinction between real and financial activities of MNEs, ${ }^{84}$ the risks of an economy-wide capital decumulation and deterring foreign portfolio investors and inbound FDI, and potentially substantial welfare losses and transition difficulties, including the need for special depreciation allowances or provisions for immediate write-offs. These are each dealt with in turn as follows.

\subsubsection{Theoretical desirability}

In addition to attaining funding neutrality by denying all deductions at corporate level for dividends and interest paid to shareholders and debt-holders, a CBIT also exempts from tax items at the level of the recipient by applying to individuals, corporations, exempt entities and non-residents. ${ }^{85}$ This attains neutrality of organisational form. So, in principle, the CBIT makes personal tax on corporate source income redundant. ${ }^{86}$ The CBIT greatly reduces the distinction between retained and distributed earnings (depending on the treatment of capital gains). Further, unlike a cash flow tax, assets are depreciated over their lifetime under the CBIT, as they would be under a conventional income tax, thereby taxing the normal return on capital. ${ }^{87}$

\footnotetext{
${ }^{84}$ Auerbach AJ, 'Tax Reform in the 21st Century', in: Diamond J and Zodrow G (eds.) Fundamental Tax Reform: Issues, Choices, and Implications (Cambridge, MA: MIT Press, 2008) 27-74, 49.

${ }^{85}$ Cnossen S, 'Company Taxes in the European Union: Criteria and Options for Reform' (1996) 17(4) Fiscal Studies 67, 86.

${ }^{86}$ Sørensen and Johnson, above n 6, 213.

${ }^{87}$ Cnossen, above n 85 .
} 


\subsubsection{Broadening the tax base}

Leading commentators Sørensen and Johnson maintain that if the CBIT is accompanied by a lower statutory tax rate, domestic business tax revenue would become less vulnerable to international profitshifting through transfer pricing and thin capitalisation. ${ }^{88}$ This proposition is widely supported in the literature, as the growing opportunities for international income shifting strengthens the case for a policy of tax-cut-cum-base-broadening. ${ }^{89}$

On the other hand, the IMF has observed that even though a standalone CBIT broadens the tax base it also increases capital costs. ${ }^{90}$ Since the CBIT increases the cost of capital, a lower number of profitable investments which offer the minimum required rate of return will be available, resulting in less investments being carried out, implying that each firm will operate at a lower capital intensity. The literature has observed that this would result in an economy-wide capital decumulation. The literature also suggests that firms will reduce their labour demand, gross wages would decrease and even though a lower tax rate would apply, this would not be enough to compensate for the negative effects of the reform. ${ }^{91}$

\subsubsection{Attracting international investment}

Further, in the context of a small, open economy such as Australia, leading commentators Sørensen and Johnson suggest that the CBIT is an attractive option, despite the obvious disincentive of denying debt deductibility, as it would attract more inbound FDI with positive spill-overs on the domestic economy. ${ }^{92}$

However, there are three issues with Sørensen and Johnson's position. First, there are no real-world examples of CBIT systems to substantiate this inference. ${ }^{93}$ Second, since the CBIT involves a sourcebased tax on the normal return to capital, ${ }^{94}$ it is likely to generate significant distortions by deterring foreign portfolio investors. Third, without first lowering corporate tax rates it is unclear how denying debt deductions (thereby raising the cost of debt and, in turn, rendering fewer investments profitable at the margin) would attract more inbound FDI. ${ }^{95}$ This is supported by leading commentators such as Radulescu and Stimmelmayr, who are sceptical that the CBIT would benefit a small, open economy, since most countries would likely want to attract investors while broadening their tax base. ${ }^{96}$

Contrary to the assumption that a CBIT would encourage international investment, Radulescu and Stimmelmayr's simulation results suggest the investment incentives produced by a CBIT would be outweighed by the decline in investment, wages, disposable income, consumption and ultimately welfare.

Accordingly, governments would need to be careful when determining how to finance the CBIT. Simulation results suggest that if the CBIT reforms are financed by a change in the GST/VAT rate rather than the corporate tax rate, introducing a CBIT would have negative consequences for investment. Also, if the implementation of a CBIT was not accompanied by special depreciation allowances or provisions for immediate write-offs, it could even lead to welfare losses. ${ }^{97}$ Even though

\footnotetext{
${ }^{88}$ Sørensen and Johnson, above n 6, 213.

${ }^{89}$ See further, Sørensen and Johnson, above n 6, 213.

${ }^{90}$ Fiscal Affairs Department, above $\mathrm{n} 64$.

${ }^{91}$ Radulescu DM and Stimmelmayr M, 'ACE vs. CBIT: Which is Better for Investment and Welfare?' (2007) 53(2) CESifo Economic Series 294.

92 Sørensen and Johnson, above n 6, 213.

${ }^{93}$ De Mooij RA, 'Tax Biases to Debt Finance: Assessing the Problem, Finding Solutions' (IMF Staff Discussion Note SDN/11/11, 3 May 2011).

${ }^{94}$ Sørensen and Johnson, above n 6, 213

${ }^{95}$ De Mooij RA and Devereux MP, 'An applied analysis of ACE and CBIT reforms in the EU' (2011) 18(1) International Tax and Public Finance 93, 98.

${ }^{96}$ Radulescu and Stimmelmayr, above $\mathrm{n} 91$.

${ }^{97}$ Radulescu and Stimmelmayr, above n 91.
} 
these simulation results are very sensitive to the magnitude of the parameters, Radulescu and Stimmelmayr posit that it is clear that the pure CBIT would not produce favourable results. ${ }^{98}$

\subsubsection{Transitional difficulties}

In addition to the practical obstacles associated with implementing the CBIT; namely, that it can only be implemented gradually over a fairly long time horizon, it is also unclear how to best mitigate the transitional difficulties in dealing with pre-existing debt issued in full expectation of deductibility ${ }^{99}$ and the short-run risk of the CBIT amplifying financial distress. ${ }^{100}$ The CBIT also presents significant issues with MNEs being unable to claim foreign tax credits in their home country, ${ }^{101}$ and the literature suggests that this may exacerbate capital decumulation. Further, financial institutions would be paying little or no corporate income tax under the CBIT; having no tax due on interest received, and noninterest deductible costs. ${ }^{102}$ Despite suggesting that in aggregate this might be more than offset by increased payments by other companies, the literature does not specifically address how this would be acceptable from both a political and a revenue base protection perspective.

It is clear that the CBIT, a conceptual cousin of thin capitalisation rules, owes much of its popularity to the possibility of a lower statutory corporate tax rate. ${ }^{103}$ However, the disadvantages associated with a CBIT provide support for the position that it is not the undeniable fundamental reform of choice, with some leading commentators showing a strong preference for both the ACE and the ACC over the CBIT. ${ }^{104}$ The literature pertaining to these reform alternatives are examined in the subsequent sections.

\subsection{ALLOWANCE FOR CORPORATE EQUITY}

The literature generally considers that the ACE eliminates the debt bias by allowing a deduction for the nominal cost of equity financing, in addition to existing debt deductibility, thereby equalising the tax treatment of debt and equity financing.

In terms of its historical development, the ACE originated in the 1970's with the Meade Committee ${ }^{105}$ proposing alternatives to the UK tax system. This was followed by research published by leading commentators Boadway and Bruce, ${ }^{106}$ who placed the theoretical foundations for a corporate tax system that is neutral to investment financing decisions by suggesting an allowance for corporate capital (ACC) ${ }^{107}$ Unlike the ACC [section 3.3.1 below], which provides a deduction for the overall cost of capital, the ACE maintains the current deductibility of the actual cost of debt finance and allows a notional return on equity to be deductible against corporate profits. The ACE system regained interest after its implementation was put on the agenda by the IFS Capital Taxes Group, ${ }^{108}$ who recommended a practical proposal.

\footnotetext{
${ }^{98}$ Radulescu and Stimmelmayr, above n 91, 31-33.

${ }^{99}$ Chaudhry SM, Mullineux AW and Agarwal N, 'Balancing Bank Regulation and Taxation' (4 February 2014), available at: http://dx.doi.org/10.2139/ssrn.1141090.

${ }^{100}$ De Mooij, above n 58; see further, De Mooij, above n 93; Fiscal Affairs Department, above n 64, 13-14.

${ }^{101}$ Fiscal Affairs Department, above n 64, 13-14.

102 IMF, above n 82, 63.

${ }^{103}$ European Commission, above n 36.

${ }^{104}$ Sørensen and Johnson, above n 6, 215, 233.

${ }^{105}$ Institute for Fiscal Studies, The Structure and Reform of Direct Taxation (George Allen \& Unwin: 1978); available at: http://www.ifs.org.uk/docs/meade.pdf.

${ }^{106}$ Boadway RW and Bruce NDB, 'A general proposition on the design of a neutral business tax' (1984) 24(2) Journal of Public Economics 231.

${ }^{107}$ De Mooij and Devereux, above n 95, 96.

${ }^{108}$ Institute for Fiscal Studies, Equity for Companies: A Corporation Tax for the 1990S, Fourth report of the IFS Capital Taxes Group, Commentary No 26 (Chameleon Press: 1991), available at: http://www.ifs.org.uk/comms/comm26.pdf.
} 


\subsubsection{Theoretical desirability and practical feasibility}

According to the theoretical literature, the ACE has many desirable theoretical properties, the most noteworthy and widely accepted of which is funding neutrality, suggesting the ACE successfully eliminates the debt bias at the corporate level. ${ }^{109}$ This is supported by an extensive body of empirical literature ${ }^{110}$ finding that corporate income taxes directly influence capital structure, ${ }^{111}$ and that an ACE in practice ameliorates the tax-induced debt bias. ${ }^{112}$

Further advantages of the ACE include bringing the tax system significantly closer to attaining CIN/CEN, if accompanied with the elimination of withholding taxes. ${ }^{113}$ The ACE is also assumed neutral regarding marginal investment, with leading commentators Sørensen and Johnson observing "it only taxes economic rents (in excess of normal profits), without distorting marginal investment decisions". ${ }^{114}$ Even though the ACE can be characterised as a tax on economic rents, it also retains a superficial resemblance to an income tax, ${ }^{115}$ which would likely improve its prospects of being considered a feasible reform option. Further desirable properties of the ACE include its investment, capital accumulation and welfare benefits, particularly in the context of small, open economies, and its ability to lower the risk of bankruptcy by encouraging firm capitalisation. ${ }^{116}$ Moreover, the ACE system is considered insensitive to the method of tax depreciation and inflation. ${ }^{117}$ This is because accelerated depreciation for tax purposes reduces the book value of assets, decreasing the base on which ACE is calculated. The present value of this latter reduction exactly offsets the benefits of the accelerated depreciation. A similar effect is present for inflation, where an increase in profits because of inflation is offset by a higher notional return. ${ }^{118}$

However, commentators have challenged the efficiency of ACE in complex settings, citing issues such as agency problems ${ }^{119}$ and credit constraints ${ }^{120}$ would reduce its efficiency properties. ${ }^{121}$

Further, the funding neutrality property of the ACE has been challenged by commentators such as Schindler et al on the basis that in a market with free entry the ACE would distort the market

\footnotetext{
${ }^{109}$ Devereux MP and Freeman H, 'A general neutral profits tax' (1991) 12(3) Fiscal Studies 1; Chen D Lee FC and Mintz JM, 'Taxation, SMEs and Entrepreneurship' (OECD Science, Technology and Industry Working Papers 2002/09, OECD Publishing, August 2002); Klemm AD, 'Allowances for Corporate Equity in Practice' (CESifo Economic Studies, Volume 53, 2/2007, 12 June 2007) 229.

${ }_{110}$ Schepens G, 'Taxes and bank capital structure' (Working paper, Department of Financial Economics, University of Ghent, October 2013).

${ }^{111}$ See Princen S, 'Taxes do Affect Corporate Financing Decisions: The Case of Belgian ACE' (CESifo Working Paper Series No 3713, January 2012); Perez-Gonzalez and Villanueva (2012); and, Schepens, above n 110, and studies cited therein, including: Modigliani and Miller (1958), Stiglitz (1973), King (1974); Titman and Wessels (1988), Fisher, Heinkel and Zechner (1989), Ang and Peterson (1986), Long and Lalitz (1985), MacKie-Mason (1990) [the first paper to find clear evidence of substantial tax effects on the choice between issuing debt or equity], Graham (1996), Heider and Ljungqvist (2012), Kestens, Van Cauwenberge and Christiaens (2012).

${ }^{112}$ Chaudhry, above n 99; see further, Staderini A, 'Tax reforms to influence corporate financial policy: the case of the Italian business tax reform of 1997-98' (Banca D'Italia No 423, 2001), Princen, above n 111; Chen et al, above n 109; and Klemm, above n 109.

${ }^{113}$ Gammie, above n 33

${ }^{114}$ European Commission, above n 36, 64; Sørensen and Johnson, above n 6, 213.

${ }^{115}$ McLure CE, Mintz J and Zodorow GR, 'US Supreme Court Unanimously Chooses Substance over Form in Foreign Tax Credit Case: Implications of the PPL Decision for the Creditability of Cash-flow Taxes' (Working Paper 14/11, Oxford University Centre for Business Taxation, August 2014), 10.

${ }^{116}$ Radulescu and Stimmelmayr, above $\mathrm{n} 91$.

${ }^{117}$ Auerbach AJ, Devereux MP, Simpson HD, 'Taxing Corporate Income', Chapter 9 in J. Mirrlees et al (eds) Dimensions of Tax Design: The Mirrlees Review (2010) Oxford University Press; see also, Keuschnigg C, 'The Design of Capital Income Taxation: Reflections on the Mirrlees Review' 2011 Fiscal Studies, Institute for Fiscal Studies 32(3) 437-452; see further, Cooper GS, 'Implementing an allowance for corporate equity' (2012) 27 Australian Tax Forum 241-271.

${ }^{118}$ De Mooij and Devereux, above n 95, 96.

${ }^{119}$ Koethenbuerger M and Stimmelmayr M, 'Corporate taxation and corporate governance' (CESIfo Working Paper 2881, December 2009).

${ }^{120}$ Keuschnigg C and Ribi E, 'Profit taxes and financing constraints' (2013) 20(5) International Tax and Public Finance 808.

${ }^{121}$ European Commission, above n 36, 64; Sørensen and Johnson, above n 6, 213.
} 
equilibrium, suggesting that the neutrality property would no longer hold when firms are mobile. ${ }^{122}$ However, one of the limitations of this critique is that, although it refers to empirical evidence, Schindler et al do not cross-reference the experience of ACE in practice and assume that capital is perfectly elastic. Further, Schindler et al also critique the real-world corporate tax rates as too low, alluding to international tax competition placing strong pressure to decrease corporate tax rates. ${ }^{123}$

Despite acknowledging the challenges associated with cross-border flows, commentators such as Sørensen continue to advocate in favour of the ACE and maintain that it does achieve funding neutrality. ${ }^{124}$ Indeed, compared to the original proposal by Devereux and Freeman, the only difference is that in Sørensen's calculation of the equity base he subtracts net new equity provided to foreign branches to prevent investments that do not generate tax revenue from eroding the domestic tax base. Dividends received from foreign companies are included in the equity base provided they are reinvested in the home country, thereby including all domestic investment in the domestic ACE allowance. ${ }^{125}$

Further, Sørensen acknowledges that, provided there is a lack of international tax coordination, the incentive for MNEs to engage in transfer pricing will always exist. ${ }^{126}$ Despite its goal of eliminating the debt bias, the ACE literature fails to address the fundamental problem created by the arbitrary distinction in international taxation whereby equity-financed outbound investments are taxed abroad while debt-financed outbound investments are taxed at home. Leading commentators acknowledge that this is a fundamental problem with the ACE literature, going to "the heart of the question of where multinationals' profits should be taxed and whether the international tax system should maintain the existing source-basis rules" ${ }^{127}$ However, this is beyond the scope of this paper, which assumes that source-based taxation will remain in place for the foreseeable future.

\subsubsection{ACE in practice}

Since its theoretical inception, the ACE has garnered substantial support from leading academics with increasing interest from policy-makers internationally. ${ }^{128}$ Indeed, the ACE is one of the few fundamental reform proposals to have been experimented with in practice, with several countries having experimented with ACE-variants; ${ }^{129}$ including Austria (2000-2004), ${ }^{130}$ Croatia (1994$2000),{ }^{131}$ Belgium (2006-today), Brazil (1996-today), ${ }^{132}$ Italy (1997-2003 ${ }^{133}$ and 2011-today) ${ }^{134}$ and

\footnotetext{
${ }^{122}$ Schindler D, Brekke KR, Pires AJG, Schjelderup G, 'Capital Taxation and Imperfect Competition: ACE vs. CBIT' (Paper presented at Jahrestagung des Vereins für Socialpolitik 2014: Evidenzbasierte Wirtschaftspolitik - Session: Taxation IV, No D15-V1, 11 August 2014).

${ }^{123}$ Schindler et al, above n 122,17 .

${ }^{124}$ Sørensen PB, 'Swedish Tax Policy: Recent Trends and Future Challenges', Report to the Expert Group on Public Economics, Swedish Ministry of Finance, May 2010.

${ }^{125}$ Sørensen, above n 124, 299-302.

${ }^{126}$ Sørensen, above n 124, 310-311.

${ }^{127}$ Parillo KA, 'The allowance for corporate equity and the CCCTB: more efficient ways to tax corporate income?' (2012) 117-2 Worldwide Tax Daily 1, 2.

${ }^{128}$ Keuschnigg, above n 117; Gammie, above n 33; Devereux MP and Sørensen PB, 'The corporate income tax: international trends and options for fundamental reform’ (2006) European Economy, Economic Paper 264.

${ }^{129}$ Traversa, above n 12.

${ }^{130}$ Leading commentators have observed that there is limited literature in relation to the Austrian ACE. They observe that the repeal of the Austrian ACE-variant coincided with the reduction in the Austrian corporate income tax rate. Interestingly, Austria cut its $34 \%$ corporate income tax rate to the equivalent of a reduced rate on the notional return at $25 \%$ : Klemm, above n 109; see further, De Mooij R and Devereux MP, 'Alternative Systems of Business Tax in Europe: An applied analysis of ACE and CBIT reforms' (European Union Taxation Papers, Working Paper No 17, 2009).

${ }^{131}$ Leading commentators observe that the Croatian ACE-variant came close to the theoretical ideal. Similarly to the Austrian experience, the reason for its abolition was to facilitate a reduction in the corporate income tax rate from $35 \%$ to $20 \%$. Keen and King provide the leading description of the Croatian ACE experience, explaining how the system functioned and discussing different critical views of the Croatian system. They conclude that the Croatian ACE was a well-functioning, technically precise system consistent with the theoretical ideal: Keen M and King J, 'The Croatian profit tax: an ACE in practice' (2002) 23(3) Institute for Fiscal Studies 401.

${ }^{132}$ While the Brazilian ACE-variant, also known as the 'remuneration for equity', has not been repealed it is not considered to have been modelled on the theoretical ACE because it is limited to distributed profits, with leading commentators such as Klemm observing that: "For most of these firms, the Brazilian system is not an ACE system but rather one of dividend deductibility": Klemm, above n 109.
} 
Latvia (2009-2013). ${ }^{135}$ Leading commentators observe that the repeal of each of these ACE-variants was not because of any fundamental problem with the theoretical ACE, ${ }^{136}$ nor any technical flaws in the ACE system. ${ }^{137}$ Rather, the abolition of these ACE-variants was in line with the dominant trend of reducing headline corporate income tax rates in the context of 'tax-rate cut cum base broadening'. ${ }^{138}$

This paper focusses on the Belgian and Italian ACE-variants for the following three-fold rationale. First, leading commentators have described these two countries jurisdictions' ACE-variants as closest to the theoretical ACE; second, these two countries jurisdictions' ACE-variants are the only ACEvariants currently in operation; and third, these two jurisdictions' reforms are relatively welldocumented, with a substantial amount of information available online, including both extrinsic and intrinsic materials, which greatly assists the process of archival research and analysis.

The tax design criteria that were most consistently adopted by these ACE-variants were economic efficiency (with a focus on funding neutrality), international competitiveness and growth. In the Belgian Notional Interest Deduction ('Belgian NID') ${ }^{139}$ context, the literature identifies four key motivations for introducing this reform: first, regional tax rate competition; second, improving corporations' solvency by addressing the debt bias; third, replacing the coordination centre regime; and, fourth, tax neutrality. In the Italian context, the primary aims of the Italian Dual Income Tax ('Italian DIT') ${ }^{140}$ were two-fold: first, to lower the effective tax rate by reducing the debt bias; and second, to encourage FDI inflows. Subsequently, the Aiuto alla Crescita Economica ('Italian ACE' $)^{141}$ reform, introduced in 2011, aimed to first, provide for austerity measures; second, to provide

133 The Italian DIT reform package was not fully completed due to the change of the government's coalition following elections in 2001, which resulted in the repeal of the DIT in favour of a single-rate corporate tax scheme. The DIT was criticised as largely benefiting large and profitable firms, who were more likely to Issue new equity, while companies in the South and SMEs were less likely to issue equity, despite their higher cost of debt. Ironically, the abolition of the Italian DIT resulted in a higher tax burden for most companies: see further: Oropallo F and Parisi V, 'Will Italy's Tax Reform Reduce the Corporate Tax Burden?' (2007) 1 Rivista di Statistica Ufficiale 31; Santoro A, 'Ex-post evaluation of tax reforms: the case of the Italian Partial ACE' (Paper presented at XII Meeting of Public Economy, Assessment of Public Policies: Palma de Mallorca, 3-4 February 2005).

${ }^{134}$ Staderini provides an empirically evaluation of the initial Italian ACE-variant: Staderini, above n 112.

${ }^{135}$ Given the relatively recent repeal of the Latvian ACE-variant, the English-language literature has not directed much attention to outlining the reasons for said repeal. Nonetheless, the Latvian ACE-variant was repealed " $i$ ] $n$ order to compensate [for] a potential loss of tax revenues" following measures increasing tax relief on R\&D, investments in new production technologies and investment projects: Eurostat, 'Taxation trends in the European Union: Data for the EU Member States, Iceland and Norway' (Luxembourg: Publications Office of the European Union, 2014), 108; see also, European Commission, 'Tax reforms in EU member states 2014: Tax policy challenges for economic growth and fiscal sustainability: 2014 Report', European Economy 6 (Brussels: European Commission, DG ECFIN and DG TAXUD, October 2014), 36.

${ }^{136}$ Klemm, above n 109.

${ }^{137}$ Keen and King, above n 131, 417

${ }^{138}$ Keen and King, above n 131.

139 The Belgian NID (otherwise known as the "Intérêts notionnels et déduction fiscales pour capital à risque", "Notionele Interestaftrek" or "Capital Risk Deduction") allows a deduction for the notional cost of equity by multiplying the notional interest rate with the adjusted equity balance. The notional interest rate is based on the average 10-year government bond rate. For qualifying SMEs the notional interest rate is increased by $0.5 \%$. The adjusted equity balance corresponds to the accounting equity balance, as listed on the non-consolidated accounts, adjusted to prevent double counting and potential misuses. However, this calculation has received much criticism in the literature, including that companies do not need to generate new investments to benefit from the Belgian NID.

${ }^{140}$ Although inspired by the Nordic DIT, the Italian DIT was very different as it only affected capital income. It split profit into two components; ordinary and above-normal income, taxing the former at $19 \%$ and the latter at $37 \%$. The imputation rate was set by reference to market rates on both public and private bonds, with scope to raise this rate up to $3 \%$ over market interest rates to commensurate for the higher risk of equity finance. The equity base was calculated by reference to the changes in capital contributions and retained profits, with a multiplier later added to align this base to the theoretical ACE while simultaneously protecting the tax revenue base; see further, Oropallo F and Parisi V, 'Will Italy's Tax Reform Reduce the Corporate Tax Burden?' (2007) 1 Rivista di Statistica Ufficiale 31.

${ }^{141}$ As originally drafted, the Italian ACE invoked the Italian DIT in some respects. A substantial improvement on the Italian ACE is that, while the Italian DIT incentivised capitalisation by applying a reduced rate to the portion of profit identified by the notional return on capital, the Italian ACE provides a tax deduction in respect of the notional return on new equity. The imputation rate was initially fixed at 3\%, with increases to be set by reference to Treasury bonds; set at $4 \%, 4.5 \%$ and $4.75 \%$ for 2014, 2015, 2016, respectively. Further, the Italian ACE was introduced with retroactive effect, or to also apply for the whole of 2011. This ensures the Italian ACE was more closely aligned to the original ACE principles, directly and immediately allowing deductions for equity financing and not providing an upper limit to the increases in equity financing. 
a stimulus for the Italian economy thereby restoring a balanced budget by 2013 ; and, third, to achieve funding neutrality ${ }^{142}$ and thereby enhance the capital structure of Italian companies by stimulating company capitalisation. ${ }^{143}$

These ACE-variants have received considerable attention from the economic literature, which currently has a corporate tax neutrality focus. Despite the ACE literature acknowledging the relevance and importance of also considering the legal, accounting and political issues,${ }^{144}$ these aspects remain understudied. Overall, the literature is broadly separated into the following two categories: first, commentators focussing on one given jurisdiction when conducting simulation studies; or second, relatively brief legal commentary of individual jurisdictions' ACE frameworks at one point in time. ${ }^{145}$

There is a very limited literature providing a comparative analysis of ACE-variants in practice; and the literature that does so is limited to the economic paradigm, rather than providing in-depth legal analysis.

The majority of the English-language literature provides a distinct focus on economic modelling rather than engaging in any legal analysis. ${ }^{146}$ One of the exceptions is an OECD report providing a descriptive exposition with detailed reference to particular amendments and developments, yet there remains a gap in relation to a critical analysis geared at suggesting design improvements for similar reforms in the future. ${ }^{147}$

A recent contribution in this area has been the comparative analysis of the Belgian and Italian ACEvariants by Zangari, ${ }^{148}$ who presents the case for why the design of the Italian ACE-variant allows for a more robust reform than the Belgian NID; namely, due to its anti-avoidance framework. However, Zangari refers to the Belgian and Italian ACE-variants as "opposite reference points", ${ }^{149}$ which is contrary to the description provided by De Mooij and Devereux; specifically, that these two ACEvariants are the closest to the theoretical ACE. ${ }^{150}$ Further, despite providing a comparison between the technical aspects of these ACE-variants in practice, Zangari does not provide an in-depth legal analysis.

Accordingly, there remains scope in the literature to provide a more thorough comparative analysis, with an emphasis on legislative drafting and underlying policy intentions for amendments over time coupled with a good tax design principle assessment. This is the focus of further research by the author. Another aspect of the ACE that has received little attention in the literature to date is that ACE-based reforms have potential to be applied as part of a broader anti-avoidance framework. It is plausible that this would be particularly useful when dealing with cross-border issues. ${ }^{151}$ Subsequent research by the author will explore the relationship between the ACE and cross-border anti-avoidance rules in practice from a legal perspective, which is a current gap in the literature.

Importantly, the Italian ACE also applies to corporations, individual firms and limited partnerships, the inclusion of which promotes neutrality in organisational form. See further, Institute for Fiscal Studies, Equity for Companies: A Corporation Tax for the 1990s, Fourth report of the IFS Capital Taxes Group, Commentary No 26 (Chameleon Press: 1991).

${ }^{142}$ Visco I, 'Fact-finding with regard to the decree law containing urgent measures for growth, equity and the consolidation of the public finances', Address by the Governor of the Bank of Italy, Rome, 9 December 2011.

${ }^{143}$ Panteghini P, Parisi ML and Pighetti F, 'Italy's ACE Tax and Its Effect on a Firm's Leverage' (Discussion Paper No 2012-31, Economics E-Journal, 27 June 2012).

${ }^{144}$ Auerbach et al, above n 117; see also, Keuschnigg, above n 117; see further, Cooper, above n 189.

${ }^{145}$ OECD, above $\mathrm{n} 81,130-133$.

${ }^{146}$ Staderini, above n 112; Giannini S, 'Le riforme italiane nella tassazione di impresa negli anni '90 in una prospettiva europea', (Paper presented at Seminario di Economia Pubblica Istituto di Economia e Finanza: Università Cattolica del Sacro Cuore, 22 February 2001); Oropallo F and Parisi V, 'Will Italy's Tax Reform Reduce the Corporate Tax Burden?' (2007) 1 Rivista di Statistica Ufficiale 31; Federici D and Parisi V 'Corporate taxation and exports' (MPRA Paper No 41012, Munich Personal RePEc Archive, 3 September 2012).

${ }^{147}$ OECD, Action Plan on Base Erosion and Profit Shifting (Paris: OECD Publishing, 2013).

${ }^{148}$ Zangari E, 'Addressing the Debt Bias: A Comparison between the Belgian and the Italian ACE Systems' (European Commission Taxation Papers, Working Paper No 44, July 2014), 49.

${ }^{149}$ Zangari, above n 148, 6 .

${ }^{150}$ De Mooij and Devereux, above n 130.

${ }^{151}$ Bond S, 'Company Tax Issues' (Presentation delivered to The Institute for Fiscal Studies, 2006). 
The studies providing assessments of ACE-variants in practice tend to be focussed on the cost of capital, ${ }^{152}$ the company tax rate with respect to the pre-existing and subsequent systems, ${ }^{153}$ and the effect of tax incentives on firms' capital structure. ${ }^{154}$ Several simulation studies have been conducted by leading commentators such as Keuschnigg and Dietz, ${ }^{155}$ Radulescu and Stimmelmayr, ${ }^{156}$ Fehr and Wiegard, ${ }^{157}$ and De Mooij and Devereux. ${ }^{158}$

However, research on these ACE-variants is inconclusive. In relation to the Belgian NID, econometric evidence on SMEs financial structure ${ }^{159}$ ranges from the reform having no significant effects in some studies, while other studies conducted by the same commentators but using larger datasets finding that the Belgian NID does significantly change SME leverage. ${ }^{160}$ In relation the Italian DIT, microsimulation modelling conducted by leading commentators Oropallo and Parisi ${ }^{161}$ is limited in scope because the empirical results only consider the first-round impact of the reform. Even though the post-transition period planned on more closely aligning the Italian reform to the theoretical ACE, it was abolished merely months into this stage due to a change of government in July 2001. Nonetheless, the literature contains a useful comparison between theoretical ACE and the Italian DIT in both its early and final stages, extracted in Table 4 below. ${ }^{162}$ Bordignon et al observe that the 1998 version of the Italian DIT contained provisions to assist in the regime's transition to the 'final regime'. They explain that this final regime differs from both the theoretical ACE and the reforms introduced in the Nordic countries at the beginning of the 1990s (Nordic DIT) in that the final regime is an attempt to balance conflicting tax reform goals. They observe that this results in a reform halfway between the theoretical ACE ${ }^{163}$ and the Nordic DIT. ${ }^{164}$ As shown in Table 4 below, the final regime includes an ACE-inspired tax on above-normal income (expressed as ' ${ }(\Pi-r E)$ ') but it also taxes the ordinary return (' $t * r^{*} E^{\prime}$ ). This attempts to balance the policy objective of attaining efficiency with the budgetary pressures that resulted from reducing the statutory tax rate in response to increased international tax competition.

\footnotetext{
${ }^{152}$ In the context of the Belgian NID: Colmant B, Minne P and Vanwelkenhuyzen T, Les intérêts notionnels: Aspects juridiques, fiscaux et financiers de la déduction pour capital à risqué (Belgium: Larcier, 2006); Van Campenhout G and Van Caneghem T, 'How did the notional interest deduction affect Belgian SMEs' capital structure?' (2013) 40(2) Small Business Economics 351, 352, and footnotes cited therein; see also: Burggraeve K, Jeanfils P, van Cauter K and van Meensel L, 'Macroeconomic and fiscal impact of the risk capital allowance' (2008) III National Bank of Belgium Economic Review 7, who investigate the marginal tax rate and macro-economic effects of the NID.

${ }^{153}$ In the context of the Italian DIT: Balzano S, Oropallo F and Parisi V, 'On the Italian ACE and its impact on enterprise performance: A microsimulation study' (Working Paper No 624, Società Italiana di Economia Pubblica, July 2009); Balzano S, Oropallo F and Parisi V 'On the Italian ACE and its impact on enterprise performance: A PLS-path modeling analysis' (2011) 4(2) International Journal of Microsimulation 14.

${ }^{154}$ For example, commentators such as Panier et al use the introduction of the Belgian NID as a quasi-experiment to investigate the effect of tax incentives on firms' capital structure using a difference in differences approach where the treatment group is constituted by Belgian firms whilst the control group is composed by firms located in neighbouring countries: France, Germany, Luxembourg and the Netherlands. The authors use a mix of data spanning between 2001 and 2009, concluding that the ACE significantly increased the capitalisation of firms, mainly by encouraging higher equity levels: Panier F, Villanueva P and Pérez-González F, 'Capital Structure and Taxes: What Happens When You (Also) Subsidize Equity?', University of Stanford, 2012, mimeo.

${ }^{155}$ Keuschnigg C and Dietz M, 'A growth oriented dual income tax' (2007) 14(2) International Tax and Public Finance 191.

${ }^{156}$ Radulescu and Stimmelmayr, above $\mathrm{n} 91$.

${ }^{157}$ Fehr H and Wiegard W, 'The Incidence of an Extended ACE Corporation Tax' (CESifo Working Paper Series No 484, May 2001)

${ }^{158}$ De Mooij and Devereux, above n 95.

${ }^{159}$ Van Campenhout and Van Caneghem, above n 152.

${ }^{160}$ Kestens K, Van Cauwenberge P and Christiaens J, 'The effect of the notional interest deduction on the capital structure of Belgian SMEs' (2012) 30 Environment and Planning C: Government and Policy 228.

161 Oropallo F and Parisi V, 'Will Italy's Tax Reform Reduce the Corporate Tax Burden?' (2007) 1 Rivista di Statistica Ufficiale 31.

162 Table 4 is a partial extract; the full table contains both corporate and non-corporate sector columns: Bordignon M, Giannini A, Panteghini P, 'Reforming Business Taxation: Lessons from Italy?' (2001) 8(2) International Tax and Public Finance 191, 197-201.

${ }^{163}$ The ACE deducted an allowance for the cost of equity computed by applying the market interest rate on government bonds $(r)$ to a measure of the equity invested in the company $(E)$, thereby resulting in a tax payable calculation of ${ }_{T}(\Pi-r E)$.

${ }^{164}$ It is noteworthy that, at the company level, the Nordic DIT does not exempt the opportunity cost of equity, whereas interest costs remain fully deductible: Bordignon, Giannini and Panteghini, above n 162, 198.
} 


\begin{tabular}{|c|c|}
\hline Tax Reform Scheme & Corporate Sector \\
\hline Nordic DIT & $\tau \Pi$ \\
\hline ACE & $r(\Pi-r E)$ \\
\hline $\begin{array}{l}\text { Ttalian DIT: } \\
1998 \text { tax reform }\end{array}$ & $\operatorname{Max}\left[\tau\left(\Pi-r^{*} \Delta E_{96}\right)+r^{*} r^{*} \Delta E_{96 ;} r^{\min } \Pi\right]$ \\
\hline $\begin{array}{l}\text { Italian DIT: } \\
\text { "final regime" }\end{array}$ & $\mathrm{r}\left(\Pi-r^{*} E\right)+t^{*} r^{*} E$ \\
\hline
\end{tabular}

The following sections provide a synthesis of both the Belgian and the Italian ACE-variants, examining both the English-language and the accessible foreign-language literature. A detailed longitudinal legal analysis of these ACE-variants will be conducted in further research by the author.

\subsubsection{Effectiveness in practice}

Leading commentators observe that the Italian DIT was a restricted version of an ACE system, ${ }^{165}$ whereas it is arguable that both the Belgian NID and the Italian ACE share the main characteristics of the theoretical ACE. ${ }^{166}$

In the context of both the Belgian and Italian ACE-variants, despite calls for a rate reduction and base broadening measures - contrary to the ACE's base narrowing - the advantages of the ACE system were considered to outweigh the disadvantages ${ }^{167}$ and striving for neutrality between the tax treatment of debt and equity finance ${ }^{168}$ was thought to strengthen corporations' capital structure, ${ }^{169}$ thereby improving corporations' solvency. ${ }^{170}$

In the context of the Belgian ACE-variant, it resulted in a marked increase in shareholders' equity in 2006 and 2007, due to capital contributions from both Belgium and overseas. ${ }^{171}$ SMEs were also found to have benefited from the Belgian NID, ${ }^{172}$ with companies decreasing leverage by $2-7 \%$, and $12 \%$ in the instance of banks. These results have lead commentators to conclude that the Belgian NID achieved its intended effect. ${ }^{173}$ Further, the reforms following the ECJ's judgment in Argenta Spaarbank ${ }^{174}$ may result in more neutrality in the treatment of foreign earnings in domicile states although this has not yet been specifically addressed by the literature.

On the other hand, other leading commentators suggest that the Belgian NID failed to achieve tax neutrality ${ }^{175}$ and highlight weaknesses in the reform. ${ }^{176}$ They consider that the Belgian NID failed to ensure tax neutrality with respect to both the source of funds and the size of investment. ${ }^{177}$ However, this evaluation was conducted in the gestation phase of the Belgian NID. Also, this evaluation differentiated between retained earnings, capital gains and equity, yet equity consists of both retained earnings and capital gains.

\footnotetext{
${ }^{165}$ Bordignon et al, above n 162; Balzano et al, above n 153.

${ }^{166}$ Zangari, above n $148,45$.

${ }^{167}$ In the Belgian context: Van Glabbeek S, Eigen vermogen, eigen behandeling? (Masters Thesis, Tilburg University, 2010); De Callatay E and Thys-Clément F (Eds.), The Return of the Deficit: Public Finance in Belgium over 2000-2010 (Belgium: Leuven University Press, 2013); Chaudhry, above n 99.

${ }^{168}$ In the Italian context: Visco, above n 142.

${ }^{169}$ In the Belgian context: Princen, above n 111; in the Italian context: Panteghini et al, above n 143; in the Italian context: Bernardi L 'Some issues on the Italian tax reforms and the European tax environment' (Working Paper No 457, Società Italiana di Economia Pubblica, September 2005).

${ }^{170}$ In the Belgian context: Van Campenhout and Van Caneghem, above n 152.

${ }^{171}$ Princen, above $\mathrm{n} 111$.

${ }^{172}$ Princen, above $\mathrm{n} 111$.

${ }^{173}$ Burggraeve et al, above n 152; Princen, above n 111; Schepens, above n 110.

${ }^{174}$ Argenta Spaarbank NV v Belgische Staat, C-350/11, 4 July 2013 (Belgium) ('Argenta Spaarbank').

${ }^{175}$ Gérard M, 'Belgium Moves to Dual Allowance for Corporate Equity' (2006) 4 European Taxation Journal 156.

${ }^{176}$ Genser B and Reutter A, 'Moving Towards Dual Income Taxation in Europe' (2007) 63(3) Public Finance Analysis 436.

${ }^{177}$ Gérard M, 'A quick valuation of Belgian notional interest' (Working Paper, Louvain School of Management, 2009).
} 
In the context of the Italian ACE-variants, the majority of the English-language literature is focussed on initial comments on, for example, how the Italian ACE could favourably impact Italian investments carried out by foreign groups and descriptive commentary on the legislative provisions. ${ }^{178}$ On the other hand, the Italian-language literature contains very detailed and thorough analysis of the legislative provisions and relevant explanatory memoranda and cross-references the treatment under the former Italian DIT. ${ }^{179}$ However, unlike the former Italian DIT, there is little attention in the literature on the trade-offs to implementation of the Italian ACE. Another issue with the Italianlanguage literature is that the commentators merely identify problematic tax treatments rather than presenting explanatory case studies or suggestions for improvement, which would assist in policy development. ${ }^{180}$ Yet, this is understandable given the intended audience of these practitioner briefing notes. Even though the Italian-language literature contains very detailed and thorough analysis of legislative provisions, there is little emphasis on considering other jurisdictions' ACE-variants, ${ }^{181}$ or engaging in a longitudinal analysis and evaluating economic and conceptual reasons for any amendments. ${ }^{182}$ These all signal gaps in the English-language literature.

Overall, in the context of both the Belgian and the Italian ACE-variants, there is a gap in the literature regarding the more specific funding neutrality aspects of these ACE-variants and their suitability in the cross-border anti-avoidance context, which at present is generally overlooked in the literature. Accordingly, a detailed legal comparative analysis of the Belgian and Italian ACE-variants will form the basis of a subsequent paper by the author.

\subsubsection{No need for thin capitalisation rules?}

The theoretical literature generally assumes that if a fundamental reform proposal such as an ACE were to be adopted there would then be no need for thin capitalisation rules.

Leading commentators such as Gammie observe that "ACE clearly reduces thin capitalisation issues" ${ }^{183}$ so if domestic-level fundamental reforms such as the ACE were implemented then there would no longer be any need for thin capitalisation rules because debt and equity would be treated equally under the ACE. Other leading commentators support the proposition that thin capitalisation rules would no longer be required (or, at least, could be simplified) under an $\mathrm{ACE},{ }^{184}$ observing as follows: "the ACE makes thin capitalization rules redundant"; ${ }^{185}$ "the more symmetric treatment of debt and equity under an ACE mean that thin capitalisation rules (which guard against excess debt financing) should no longer be required"; ${ }^{186}$ and, "thin capitalisation rules are therefore not required under the ACE tax system". ${ }^{187}$ This inference can be extrapolated beyond thin capitalisation rules to also include other interest deduction limitation rules. ${ }^{188}$ For completeness, this position has been challenged in the literature, with Cooper observing that "This is a bold claim, but it seems implausible ... in a world with ACE but without thin capitalisation rules, Australia gets either less corporate tax

\footnotetext{
178 Visco, above n 142; Leone FG and Zanotti E, 'Notional Interest Deduction Regime Introduced' (2012) 52(8) European Taxation Journal 432.

179 Istituto di Ricerca dei Dottori Commercialisti e degli Esperti Contabili, 'L'Aiuto alla Crescita Economica (ACE)' (Circular No 28, 29 March 2012).

${ }^{180}$ Ciani F, 'Simmetrie fiscali nelle nuove patrimonializzazioni delle imprese Allowance for Corporate Equity (ACE)' (2012) 79(14) Bollettino Iributario d'Informazioni 1052.

${ }^{181}$ Zangari, above n 148, 45.

${ }^{182}$ Assonime, 'La disciplina dell-ACE (aiuto alla crescita economica)' (Direct Taxation, Circular No 17, 7 June 2012).

${ }^{183}$ Gammie, above n 33, 240.

${ }^{184}$ Fischer H and Lohbeck A, 'The debt-equity condundrum Germany: Summary and Conclusions', in: International Fiscal Association, The Debt-Equity Conundrum, Cahiers de droit fiscal international, 97b(2) (The Hague, The Netherlands: Sdu Uitgevers, 2012).

${ }^{185}$ De Mooij and Devereux, above n 95, 96.

${ }^{186}$ The Henry Review, above n 68.

${ }^{187}$ OECD, above n $81,157$.

${ }^{188}$ The ACE is also considered a viable alternative to the interest deduction ceiling rule: Fischer and Lohbeck above n 184 , 307-327; see further, Rumpf, Zinsbereinigung des Eigenkapitals im internationalen Steuerwettbewerb - Eine kostengünstige Alternative zu "Thin Capitalization Rules"?, arqus Discussion Papers in Quantitative Tax Research, August 2008.
} 
or no corporate tax". ${ }^{189}$ However, this critique of ACE's suitability as an alternative to thin capitalisation rules prioritises the design criteria of sustainability over funding neutrality and possibly assumes that most MNEs engage in international debt shifting. This position is contrary to the empirical findings of Ruf and Schindler who, as noted earlier [supra section 2.2.1.1.2] found that the evidence merely supports the proposition that, for the average MNE, there is no need to implement thin capitalisation rules because of their nominal impact. ${ }^{190}$ They observe that the mismatch between anecdotal evidence provided by tax consultants and auditors, and the relatively weak empirical evidence concerning all MNEs is attributable to the fact that most MNEs do not engage in international debt shifting. Rather, they believe that only a few large MNEs engage in aggressive tax planning and that thin capitalisation rules cause significant collateral damage by requiring non taxaggressive MNEs to bear the administrative burden of these complex rules. ${ }^{191}$

A research gap that remains in the literature is an exploration of the inverse; namely, whether it is possible to address the cross-border debt bias by adapting fundamental reforms into the cross-border context to improve or replace existing thin capitalisation rules.

None of the ACE-variants in practice were designed with the intention of being alternatives to thin capitalisation rules, nor has the literature yet examined the correlation between implementing (or reducing the scope of) an ACE-variant and limiting (or tightening) thin capitalisation rules. Accordingly, the author will test this relationship in subsequent research. Preliminary findings in the extrinsic materials already analysed indicate that there is a relationship in practice. When the scope of an ACE-variant is restricted there is a heightened perception on the part of policymakers that MNEs are setting up thin capitalisation structures, which provides the impetus for increasing the scope of, and tightening, thin capitalisation rules. For example, the explanatory materials to a 2012 amendment to the Belgian NID refers, albeit in passing, to the need to tighten thin capitalisation rules following a series of amendments restricting the scope of the Belgian NID. ${ }^{192}$

\subsubsection{Safeguarding the tax base}

Despite the theoretical desirability and practical effectiveness of the ACE, governments consistently conclude that it is not a suitable reform option predominantly due to revenue neutrality concerns. This is despite policymakers in recent reviews conducted by, inter alia, Australia's Henry Review and BTWG ${ }^{193}$ the UK's Mirrlees Review ${ }^{194}$ suggesting that a more holistic approach to genuine reform ought not to be impeded by the requirement of revenue neutrality.

While the ACE system results in a narrower tax base and therefore lower tax revenues, which the theoretical literature anticipates is one of its primary drawbacks, it is efficient to tax normal returns at a lower rate than economic rents. So, if individual countries were to adopt an ACE system in response

\footnotetext{
${ }^{189}$ Cooper GS, 'Implementing an allowance for corporate equity' (2012) 27 Australian Tax Forum 241-271, 266.

${ }^{190}$ Ruf and Schindler, above n 57, 9.

${ }^{191}$ Ruf and Schindler, above n 57, 9-10.

192 "Cependant, avec la perspective de la limitation de cette déduction, qui a déjà été concrétisée en partie par l'adoption de la loi du 28 décembre 2011 portant des dispositions diverses et qui est poursuivie par les dispositions d'un autre projet visant à supprimer les possibilités de report de la déduction non accordée en cas d'absence ou d'insuffisance des bénéfices d'une période imposable, sont apparues des indications qu'un certain nombre de grandes entreprises envisagent de mettre en place des constructions faisant appel à la sous-capitalisation.": La Chambre des représentants de Belgique - Belgische Kamer van volksvertegenwoordigers [House of Representatives], Project de Loi-Programme du 24 février 2012 - Ontwerp van Programmawet van 24 februari 2012 [Bill of 24 February 2012, Explanatory Notes] (DOC 53 2081/001), Article 139, 96 (Belgium).

193 "Australia, in the future, should consider moving the company income tax system towards a business level expenditure tax, such as an allowance for corporate equity, subject to further international development of tax models": The Henry Review, above n 68, 42-43; and, "... full implementation of an ACE would not be possible within the revenue neutral constraint imposed by the Working Group's terms of reference with the base broadening options identified in this paper": Australian Government, 'Business Tax Working Group: Final Report', Chapter 3: Allowance for Corporate Equity, November 2012, 12.

194 "Our recommendations are thus to introduce an ACE without increasing the corporate tax rate, to accept that less revenue will be collected from the corporate tax": Mirrlees et al, "The Mirrlees Review: Conclusions and Recommendations for Reform’ (2011) 32(3) Fiscal Studies 331, 351.
} 
to growing capital mobility, the resulting tax structure might be desirable from both a national and an international perspective. Since some rents earned by MNEs are internationally mobile, national governments acting in their own interest are likely to choose a lower tax rate on rents than would otherwise be optimal from a global perspective. ${ }^{195}$ Accordingly, achieving the appropriate level of taxation is therefore likely to require substantial international policy coordination. While this is a key setback, it is important to note that this requirement applies to many taxes to some degree.

Further, there is an assumption in the theoretical literature that by exempting normal returns from tax, the ACE tends to require higher statutory tax rates to secure the desired revenue (and maintain revenue neutrality). This assumption most likely stems from Devereux and Freeman, ${ }^{196}$ where the increase in the corporate tax rate necessary to finance an ACE was estimated. This could be characterised as the Achilles' heel of the ACE because it is highly unlikely for governments to legislate higher corporate tax rates for both budgetary reasons and also because, ironically, this would deter inward investment by highly profitable MNEs and provoke outward profit-shifting through transfer pricing. ${ }^{197}$ Further, leading commentators also recognise the down-sides in relying on the premise that the ACE reform would be revenue neutral through a higher profit tax rate, as this would adversely affect investment decisions of credit-constrained firms ${ }^{198}$ and lead to negative economywide repercussions generally. ${ }^{199}$

However, the theoretical literature regarding the necessity of increasing the corporate tax rate to finance the ACE tends to overlook an observation made by King, as follows: ${ }^{200}$

"At first sight it might appear that a tax which offers such generous investment incentives would require a higher tax rate to raise the same amounts of revenue as under the current corporate tax system. A little reflection, however, demonstrates that this is not the case. The new tax base would imply the abolition of investment tax credits and grants, and also of deductions for interest payments on new loans and for dividends"

Further, according to the Meade Committee report, there is no reason to suppose that the corporate tax rate would have to rise if the base were switched to a corporate cash flow base. ${ }^{201}$ However, given the period surveyed there was from 1964-1974, it is most likely that the partial equilibrium calculations are no longer relevant as "... the most important developments affecting business taxation since the Meade Report in 1978 have been the growth of multinational businesses and cross border ownership of companies" ${ }^{202}$ More recent estimates of the revenue loss of ACE systems estimate reductions in corporate income tax revenue between $15 \%^{203}$ to over $30 \% .^{204}$

However, it is arguable that the benefits of the ACE from an economy-wide perspective may not be adequately considered in these assessments. For example, in relation to Keen and King's estimate, ${ }^{205}$ some of the investment would never have taken place under a higher marginal effective tax rate. This suggests the revenue loss may be overestimated. Further, leading commentators highlight the literature observation that reducing tax on foreign income can advance both domestic and global welfare. ${ }^{206}$ Leading commentators agree that the ACE encourages further investment, economic

\footnotetext{
${ }^{195}$ Devereux MP and Griffith R, 'The taxation of discrete investment choices' (Institute for Fiscal Studies Working Papers W98/16, February 1999); Hines JR, 'Lessons from Behavioural Responses to International Taxation' (1999) 52(2) National Tax Journal 305.

${ }^{196}$ Devereux and Freeman, above n 109.

${ }^{197}$ Auerbach et al, above n 117; Van Campenhout and Van Caneghem, above n 152.

${ }^{198}$ Van Campenhout and Van Caneghem, above n 152.

${ }^{199}$ Radulescu and Stimmelmayr, above $\mathrm{n} 91$.

${ }^{200}$ King MA, 'The Cash Flow Corporate Income Tax', Chapter 12, in: The Effects of Taxation on Capital Accumulation, edited by Feldstein M (Chicago, University of Chicago Press, 1987); King provides the following elaboration: "A full-scale calculation of the tax rate that would be required to raise the same amount of revenue would involve a general equilibrium analysis of the incentive effects of the new tax. This is beyond our scope here." [394-395].

${ }^{201}$ King, above n 200, 395.

${ }^{202}$ Auerbach et al, above n 117; see also, Keuschnigg, above n 117; see further, Cooper, above n 189.

${ }^{203}$ De Mooij, above n 93.

${ }^{204}$ Keen and King, above n 131.

${ }^{205}$ Keen and King, above n 131.

${ }^{206}$ Desai and Hines, above n 23, 497.
} 
growth and welfare. So, it is arguable that those additional activities will in turn result in tax revenues. Admittedly, the precise magnitude of this potential is not readily quantifiable and is beyond the scope of this paper.

Understandably, at the current economic juncture where tax base erosion and revenue base protection are key areas of concern for policymakers, it is more pragmatic to finance the ACE reform with other tax reforms. ${ }^{207}$ For example, leading commentators estimate that an increase in the VAT/GST to finance the ACE would increase employment and GDP, while recovering more than $75 \%$ of the initial fiscal costs in the long-run. ${ }^{208}$ Other simulation results indicate that introducing the ACE at both the corporate and non-corporate levels (accompanied by the half-income principle of dividend taxation on households) would provide significant positive effects for investment, capital accumulation and welfare. ${ }^{209}$ The budgetary cost can also be reduced by limiting the ACE deduction to new investment only, however this may not be entirely consistent with the theoretical conception of the ACE base.

Accordingly, it is useful to examine the ACE-variants in practice. Chen et al, ${ }^{210}$ Keen and King, ${ }^{211}$ Klemm ${ }^{212}$ and Massimi and Petroni ${ }^{213}$ have provided comprehensive evaluations of these ACEvariants in practice, concluding that ACE-variants were quite successful in practice and did not have significant negative effects on corporate tax revenues. ${ }^{214}$ Importantly, these leading commentators also observe that, of the ACE-variants no longer in operation, their abolition was attributable to political aspirations and the willingness of governments to introduce lower overall corporate tax rates, rather than to any fundamental design flaws in the ACE-variant system. The exception is the recent abolition of the Latvian ACE-variant which, at time of writing, the literature is silent on. Yet, an appendix to a recent European Commission document confirms the Latvian ACE was abolished "to compensate for a potential loss of tax revenues". ${ }^{215}$

Even though the adoption of an ACE generally results in revenue losses, commentators agree that "ACE passed its first practical test" designed to limit these losses. ${ }^{217}$ To provide a more holistic evaluation it is also necessary to consider the flow-on benefits of the ACE in practice, such as investment, economic growth and employment.

\subsubsection{The revenue base and the "equity" base}

One of the most substantial hurdles to implementing the ACE is the political aversion to non-revenue neutral reform. Budget constraints were at the forefront of both Belgian and Italian policymakers concerns when considering implementation of the ACE.

In the context of the Italian ACE, the government decided not to extend the calculation of "equity" to the entire equity stock mostly for revenue base protection reasons. This was despite their belief that extending the calculation of equity to the entire equity stock would eliminate the remaining tax advantage of debt, and would likely benefit the financial soundness of firms and their ability to finance medium and long-term investments. ${ }^{218}$ Further, with an estimated cost of $€ 4$ billion (i.e. about

\footnotetext{
${ }^{207}$ See, for example, Sørensen and Johnson, above n 6, 232.

${ }^{208}$ De Mooij and Devereux, above n 95, 98 .

${ }^{209}$ Radulescu and Stimmelmayr, above $\mathrm{n} 91$.

${ }^{210}$ Chen et al, above $\mathrm{n} 112$.

${ }^{211}$ Keen and King, above n 131.

${ }^{212}$ Klemm, above n 109.

${ }^{213}$ Massimi and Petroni, above $\mathrm{n} 28$

${ }^{214}$ Keen and King, above n 131.

${ }^{215}$ Eurostat, 'Taxation trends in the European Union: Data for the EU Member States, Iceland and Norway' (Luxembourg: Publications Office of the European Union, 2014), 108; contrast this with the latest appendix on ACE in practice which mentions all of the other ACE-variants yet entirely omits the Latvian ACE: De Mooij RA and Saito I, 'Japan's Corporate Income Tax: Facts, Issues and Reform Options' (IMF Working Paper WP/14/138, 4 August 2014), 42-43.

${ }^{216}$ Keen and King, above n 131, 417.

${ }^{217} \mathrm{IMF}$, above $\mathrm{n} 82$.

218 Visco I, 'Overview of Italy's economy and banking system', Address by the Governor of the Bank of Italy, Italian Banking Association: Annual Meeting, Rome, 10 July 2013.
} 
$0.25 \%$ of GDP) this would have been affordable. ${ }^{219}$

The literature similarly reflects substantial criticism being directed at the Belgian NID as it is thought to have placed a considerable cost on public finances, and that the revenue foregone failed to boost the economy and did not serve any employment objective. ${ }^{220}$ Given the unfortunate timing leading to implementation of the Belgian NID coinciding with the GFC, there is increasing political pressure to abolish the NID on the basis that MNEs significantly (and disproportionately) benefit from it. However, macroeconomic analysis shows that the Belgian NID had only a limited negative effect on corporation tax revenues, if any. ${ }^{221}$ This is in contrast to the earlier empirical estimates from Keen and King that corporate tax revenue losses would exceed $30 \%,{ }^{222}$ with the most recent approximations by Sørensen at $10 \%$ of corporate tax revenues. ${ }^{223}$ Assuming that inflows of foreign capital have expanded the corporation tax base in Belgium, it is plausible that the introduction of the Belgian NID may have even had a positive impact on public finances. ${ }^{224}$ Further, empirical evidence shows that the introduction of the Belgian NID generated substantial dynamic effects, bringing the gross tax advantage for companies to $€ 3,035$ million by the end of $2006, € 1.2$ million higher than simulation estimates. $^{225}$

Interestingly, in the context of both the Belgian and the Italian ACE-variants, implementation of the ACE appears to have been a last-resort solution. To provide a more holistic evaluation it is also necessary to consider the flow-on benefits of the ACE in practice, such as investment, economic growth and employment.

Regarding investment and economic growth, leading commentators indicate that the Belgian NID had an undeniably considerable impact in terms of financial flows. ${ }^{226}$ Regarding the Belgian NID's impact on the real economy, it seems to have been fairly limited in the short term, but it may become more noticeable in the medium term. ${ }^{227}$ In terms of employment, Burggraeve et al also consider that the post-coordination centre regime decline in employment would have been larger without the introduction of the Belgian NID. They indicate that in the new finance centres being set up by MNEs have seen a positive (albeit marginal) impact on employment. ${ }^{228}$ However, it is also important to note that it takes time for firms to increase their employment, so this result is not surprising.

In its early stages, the Italian DIT was limited to new equity to limit short-term revenue losses ${ }^{229}$ and fulfil the public finance obligations within the EU. ${ }^{230}$ It was later subject to changes mainly aimed at accelerating its application, ${ }^{231}$ which aligned the Italian DIT closer to the theoretical ACE. Specifically, a multiplier which enabled normal profits to be computed on the enterprise's entire capital stock rather than on capital increases was utilised. ${ }^{232}$ The reason for the introduction and gradual increase of the multiplier was due to balance the conflicting aims of complying with Italy's public finance obligations under the European Monetary Union process ${ }^{233}$ while also accelerating the application of the Italian DIT.

However, as seen in the Belgian NID, when the equity base of the ACE is aligned to the theoretical ideal there is scope for criticism on the basis that companies did not need to generate new investments

\footnotetext{
${ }^{219}$ Arachi G, Bucci V, Longobardi E, Panteghini P, Parisi ML, Pellegrino S and Zanardi A, 'Fiscal Reforms during Fiscal Consolidation: The Case of Italy' (Working Paper No 2, Department of Economics and Statistics Working Paper Series, February 2012); Panteghini et al, above n 143.

${ }^{220}$ Princen, above $\mathrm{n} 111$.

${ }^{221}$ Burggraeve et al, above n 152.

${ }^{222}$ Keen and King, above n 131.

${ }^{223}$ Sørensen, above n 124.

${ }^{224}$ Burggraeve et al, above $\mathrm{n} 152$.

${ }^{225}$ Burggraeve et al, above $\mathrm{n} 152$.

${ }^{226}$ Burggraeve et al, above $\mathrm{n} 152$.

${ }^{227}$ Burggraeve et al, above n 152.

${ }^{228}$ Burggraeve et al, above $\mathrm{n} 152$.

${ }^{229}$ Bordignon et al, above n 162.

${ }^{230}$ Oropallo and Parisi, above n 161.

${ }^{231}$ Balzano et al, above n 153.

${ }^{232}$ Oropallo and Parisi, above n 161; Balzano et al, above n 153.

${ }^{233}$ Federici and Parisi, above n 146.
} 
to benefit from the ACE. ${ }^{234}$ A popular alternative to the formulation of the "adjusted" equity balance ${ }^{235}$ is to use retained earnings. ${ }^{236}$ While this would encourage reinvestment and be effective in countries with high corporate tax rates, ${ }^{237}$ the English-language literature is silent on the legal issues relevant to this alternative, which will be explored by the author in subsequent research. Despite its digression from the theoretical ideal, the Italian ACE literature suggests that the use of an incremental equity base results in a more robust system in practice. ${ }^{238}$

\subsubsection{Political controversy and legal uncertainty}

Both the Belgian and the Italian ACE-variants have been subject to much political controversy following criticisms that the ACE reform disproportionately benefits MNEs and presents a substantial tax leak. This resulted in a plethora of legislative amendments which in turn has exacerbated concerns surrounding legal certainty. This raises one of the key issues in practice; it is difficult to create enough simplicity to give businesses a feeling of legal certainty about fundamental reform while instilling the voting public's confidence in said reform. ${ }^{239}$

Since its inception, the Belgian NID has been the subject of debate on whether it should be abolished, ${ }^{240}$ with political controversy regarding its economic benefits, effectiveness, costs and legal validity. Belgium has the second highest headline corporate income tax rate in the EU, ${ }^{241}$ yet the socialist parties were opposed to directly reducing the CIT rate. ${ }^{242}$ The Belgian NID was originally introduced purely on politically grounds. This resulted in much criticism of the motivations for implementing the Belgian NID from leading academics such as Vanistendael, who described the Belgian NID as "a prime example of what happens when you hold [on to] political and social symbols". ${ }^{243}$ Vanistendael considers that policymakers could have increased tobacco and alcohol taxes, or increased the VAT instead of implementing an ACE-variant.

Similarly, in the Italian context, the implementation of two ACE-variants, with one abolished following a change in government, within the past decade exemplifies the highly controversial nature of the ACE reform.

While there are many issues within this area, the focus of this section is two-fold; first, reviewing the literature in relation to the implications for SMEs; and second, examining the difficulties in assessing the long-term benefits of the ACE in practice.

Regarding the Italian DIT, the empirical evidence regarding its impact on SMEs is ambiguous, with contradictory evidence emerging from the literature. ${ }^{244}$ On one hand, the first ex-post evaluation of the Italian DIT found that tax reductions were not obtained by SMEs. This evaluation observed that the

\footnotetext{
${ }^{234}$ Princen, above n 111.

${ }^{235}$ Specifically, shareholders' equity is reduced by (i) the net tax value of the company's own shares; (ii) financial fixed assets consisting of participating interests and other equity; (iii) shares issued by investment companies whose income, if any, is deductible as finally taxed income; (iv) net book value attributed to permanent establishments or immovable property located abroad; (v) net book value of assets which are unreasonably in excess of business needs; (vi) the book value of asset items held as an investment but that are not destined to generate regular income; (vii) the book value of property used for private purposes; (viii) capital gains expressed but not realized; and (ix) capital subsidies.

${ }^{236}$ Poutziouris P, Chittenden F and Michaelas N, 'Evidence on the tax and investment affairs of small firms' (1999) 6(1) Journal of Small Business and Enterprise Development 7.

${ }^{237}$ mac an Bhaird C and Lucey B, 'Determinants of Capital Structure in Irish SMEs' (2009) 35(3) Small Business Economics 357.

${ }^{238}$ Zangari, above n 148, 45.

${ }^{239}$ Pompen E, 'Morrelen aan notionele intrest nekt rechtszekerheid' [2009] (October) Trends 31; Quaghebeur M, 'European Commission Questions Belgian Notional Interest Deduction' (2009) [March] Tax Notes International 1045; Van Campenhout and Van Caneghem, above n 152.

${ }^{240}$ Vanistendael F, 'Belastingaftrek op risicokapitaal. De goede weg gekozen?' [2005] (May) Algemeen Fiscaal Tijdschrift 1; Belgian Chamber of Representatives (2008) Integraal Verslag 16-1-2008, Report CRIV 52 COM067, available at: http://www.dekamer.be/doc/CCRI/pdf/52/ic067.pdf; Quaghebeur, above n 239; Pompen, above n 239.

${ }^{241}$ Eurostat, above n 215; at time of writing, Belgium still has the second highest headline corporate tax rate.

${ }^{242}$ Vanistendael F, 'Goed bestuur?' [2007] (July) Algemeen Fiscaal Tijdschrift 1; Van Campenhout and Van Caneghem, above $n 152$.

${ }^{243}$ Vanistendael, above n 242.

${ }^{244}$ Santoro A, 'Ex-post evaluation of tax reforms: the case of the Italian Partial ACE' (Paper presented at XII Meeting of Public Economy, Assessment of Public Policies: Palma de Mallorca, 3-4 February 2005).
} 
literature was unclear on whether this was because SMEs were slower to adjust to the changing tax environment or whether SMEs were simply more reliant on debt. On the other hand, subsequent research found that the Italian DIT mainly benefited new firms and less-well capitalised firms, rather than strongly capitalised companies. ${ }^{245}$ This proposition is consistent with empirical evidence that the partial abolition of the Italian DIT in 2001 (replaced by a decreased statutory corporate tax rate) harmed SMEs significantly. ${ }^{246}$ This strongly suggests that an ACE provides greater benefits for SMEs than a reduction in the headline corporate tax rate. Maffini highlights that some commentators have employed large datasets, including SMEs, to investigate the differential responses of firm's capital structure to tax. However, the leading papers have come to opposite conclusions on the implications for SMEs. ${ }^{247}$ So far the effects of the Italian ACE have been limited. This result may be due to the lack of profits available to reinvest in particular firms, and also because of the relatively small size of the Italian ACE, which leading commentators observe must be sufficiently large and permanent in the eyes of businesses if they are to be effective. ${ }^{248}$

The Belgian literature presents similar ambiguities. Even though the largest responses to changing tax incentives are found among large and new firms ${ }^{249}$ empirical evidence suggests that SMEs benefit significantly from the Belgian NID. This is because the Belgian NID encouraged SMEs to strengthen their capitalisation, ${ }^{250}$ thereby providing insulation from economic difficulties. There is a plethora of Belgian media suggesting that the NID is of little benefit to SMEs, ${ }^{251}$ and therefore raises fairness issues. ${ }^{252}$ This is despite the $0.5 \%$ higher NID rate available for SMEs to utilise. Further, the literature also suggests that the Belgian NID is unpopular with SMEs due to its complexity, ${ }^{253}$ while simultaneously suggesting that SMEs benefit significantly from the Belgian NID as it encourages them to strengthen their capitalisation. ${ }^{254}$

Even though the full impact of the Belgian and Italian ACE-variants might only become visible in the medium-/long-term, the predominantly short-term focus of politicians and the political decision process in general requires tenable results in the short term. ${ }^{255}$ This is a substantial hurdle to implementing and maintaining ACE in practice because a lengthier sample period is required to derive meaningful results. It is also necessary to bear in mind that macroeconomic modelling has limitations; for example, Burggraeve et al recognise that to assess the Belgian NID's ex-ante effect on corporate cash flows it is necessary to know its budgetary cost, or more precisely a transfer of resources from the government to the business sector. ${ }^{256}$ However, this cost is particularly difficult to assess, since the measure relates to both new investments and entire balance sheets, thereby requiring an integration of accounting and tax definitions which is beyond the scope of their model. Similarly, regarding the Italian DIT's impact on FDI inflows, empirical evidence shows a connection between firm profitability, productivity and investment and the increased use of the Italian DIT; ${ }^{257}$ and, on the other hand, other leading commentators state there is very little evidence that the Italian DIT encouraged FDI inflows. ${ }^{258}$ Commentators such as Bordignon et al suggest that FDI inflows are

\footnotetext{
${ }^{245}$ Bordignon et al, above n 162; Oropallo and Parisi, above n 161; Balzano et al, above n 153.

${ }^{246}$ Manzo M, 'Corporate Taxation and SMEs: The Italian Experience' (OECD Taxation Working Papers, No 6, OECD Publishing, 2011).

${ }^{247}$ Maffini G, Data for research in European business taxation, in: ETPF-CEPS Conference on Financial Sector Taxation, 13/05/2013, CEPS, Brussels, Belgium. (Unpublished)].

${ }^{248}$ Panetta F, 'A Financial System for Growth' (Speech presented by the Deputy Governor of the Bank of Italy, Milan, 27 January 2014).

${ }^{249}$ Panier et al, above n 154.

${ }^{250}$ Empirical evidence suggests the NID has reduced debt-asset ratios of SMEs: see further, Kestens et al, above n 160.

251 Le soir, Milquet veut ramener le taux de l'Impôt des sociétés à 23,7\% (3 February 2013), available at: http://www.lesoir.be/177360/article/actualite/fil-info/2013-02-03/milquet-veut-ramener-taux-nominal1\%E2\%80\%99imp\%C3\%B4t-des-soci\%C3\%A9t\%C3\%A9s-33-\%C3\%A0-237.

${ }^{252}$ Burggraeve et al, above n 152; Princen, above n 111.

${ }^{253}$ Van Campenhout and Van Caneghem, above n 152.

${ }^{254}$ Empirical evidence suggests the NID has reduced debt-asset ratios of SMEs: see further, Kestens et al, above n 160.

${ }^{255}$ Van Campenhout and Van Caneghem, above n 152.

${ }^{256}$ Burggraeve et al, above n 152.

${ }^{257}$ Staderini, above n 112.

${ }^{258}$ Bordignon et al, above n 162.
} 
stunted by the lack of infrastructure, the heavy bureaucracy and the inflexible labour market, rather than tax policies such as the Italian DIT. ${ }^{259}$

\subsubsection{Selecting the $\mathrm{ACE}$ rate}

The ACE literature suggests that the risk-free ${ }^{260}$ interest rate ${ }^{261}$ is the preferred rate for the notional return on equity ('the ACE rate'). Leading commentators agree the best proxy for this is the long-term government bond rate. ${ }^{262}$

However, the use of the long-term government bond rate can result in issues at both the domestic and the international levels, which the literature has thus far remained silent on.

Domestically, the issues are two-fold. First, on a pragmatic level, if a country has a relatively fragmented or unstable financial market, there is no obvious choice for a risk-free rate. ${ }^{263}$

Second, it is arguable that the risk-free rate does not necessarily reflect the actual cost of equity for each firm. Leading commentators such as Sørensen and Johnson observe that, "in practice, the ability of the ACE to eliminate the debt bias depends crucially on ... whether actual interest rates differ from the notional return chosen to relieve equity". ${ }^{264}$ This was the rationale for the US Treasury's critique of the ACE system, which commentators such as Rumble highlight when rejecting the viability of the ACE. However, Rumble's observation that "the ACE proposal is a detailed exposition of a dividend deduction scheme" ${ }^{265}$ suggests that he has arguably conflated the ACE with dividend deductibility. The degree of non-neutrality would depend on the size of the difference between the actual and the appropriate rate of the notional interest. ${ }^{266}$ Since a substantial amount of information would be required to set the ACE rate ${ }^{267}$ this may be overly burdensome administratively, requiring different rates for different companies. ${ }^{268}$ Nonetheless, a key counter-argument is that even if the ACE rate were set at the "wrong level" this would still be preferable to a zero ACE rate, as effectively provided under the existing system. On the other hand, some commentators suggest that the ACE rate could simply equal the interest rate paid on debt financing. ${ }^{269}$

Internationally, particularly when dealing with MNEs, it is questionable that a domestic risk-free rate is the best indicator of a MNEs notional return on equity. Rather, a worldwide rate would arguably be a more suitable proxy. This has been overlooked in the context of the ACE literature, most likely due to the traditionally domestic nature of ACE reform proposals. A "worldwide debt-to-capital ratio interest limitation rule" (otherwise known as the "worldwide gearing ratio") currently exists in both the theory and practice of thin capitalisation rules, whereby interest deductions on debt financing are denied to the extent that the proportion of a company's assets exceeds the proportion of the group's worldwide third-party debt to asset ratio. ${ }^{270}$ Leading commentators also highlight that this rule is inherently suited to international harmonization, ${ }^{271}$ which would also be compatible with an ACE system. ${ }^{272}$

\footnotetext{
${ }^{259}$ Bordignon et al, above $\mathrm{n} 162$.

260 "calculated by reference to a normal commercial rate of interest, fixed by the government"; see further, Gammie, above $\mathrm{n}$ 33.

${ }^{261}$ De Mooij and Devereux, above n 95, 96.

${ }^{262}$ Gammie, above n 33; Bond SR and Devereux MP, 'On the design of a neutral business tax under uncertainty' (1995) 85(1) Journal of Public Economics 57; De Mooij and Devereux, above n 95, 96.

${ }^{263}$ Keen and King, above $n 131$.

${ }^{264}$ European Commission, above n 36, 64; Sørensen and Johnson, above n 6, 213.

${ }^{265}$ Rumble T, Synthetic equity and franked debt: Capital markets savings cures (PhD Thesis, UNSW 1998), 345 and 382.

${ }^{266}$ Keen and King, above n 131, 415.

${ }^{267}$ Boadway and Bruce, above n 106; Bond and Devereux, above n 262.

${ }^{268}$ Sørensen, above n 124; see further, Sørensen and Johnson, above n 6, 212.

${ }^{269}$ Radulescu and Stimmelmayr, above $\mathrm{n} 91$.

${ }^{270}$ Burnett, above n 11.

${ }^{271}$ Burnett, above $\mathrm{n} 11$.

${ }^{272}$ De Mooij and Devereux, above n 95.
} 
Nonetheless, in line with the dominant suggestion in the ACE literature, Table 5 below depicts the notional return on equity $\left(\mathrm{r}^{\mathrm{E}}\right)$ under the pure ACE at the risk-free interest rate. Under a pure ACE system there is no restriction on debt deductibility $\left(r^{\mathrm{D}}\right)$, so the cost of debt deductibility is effectively uncapped at the market rate. As explained above, it is questionable that an ACE equalises the tax treatment of debt and equity financing; rather, an ACE simply mitigates the debt bias. However, traditionally conceptualised as a domestic debt bias solution, a standalone ACE would not be a viable solution to the behaviour of cross-border debt shifting. In this sense, an ACE neglects the symptom. ${ }^{273}$

However, if the ACE was used to supplement thin capitalisation rules (rather than replace them, as explored in section 3.2.1.3) then the result would change. Even though the notional return on equity $\left(\mathrm{r}^{\mathrm{E}}\right)$ would remain at the risk-free interest rate, the extent of debt deductibility $\left(\mathrm{r}^{\mathrm{D}}\right)$ would now be capped. This would provide partial tax relief for both debt and equity financing, thereby nearly equalising their tax treatment. This would in turn mitigate the impact of both the symptom and the disease, as shown in Table 5 below. This presents a more robust approach in comparison to the pure ACE, which currently neglects the MNEs behavioural response of debt shifting.

\begin{tabular}{|l|l|l|}
\hline \multicolumn{2}{c}{ Table 5 } \\
\hline & ACE & $\begin{array}{l}\text { ACE plus Thin } \\
\text { Capitalisation } \\
\text { Rules }\end{array}$ \\
\hline $\begin{array}{l}\text { Cost of debt } \\
\text { deductibility }\end{array}$ & $\mathrm{r}^{\mathrm{D}}=\mathrm{r}^{\text {manapped\% } \%}$ & $\mathrm{r}^{\mathrm{D}}=\mathrm{r}^{\text {capped\% } \%}$ \\
\hline $\begin{array}{l}\text { Cost of equity } \\
\text { deductibility }\end{array}$ & $\mathrm{r}^{\mathrm{E}}=\mathrm{r}^{\text {risk-ficee } \%}$ & $\mathrm{r}^{\mathrm{E}}=\mathrm{r}^{\text {risk-ficeo } \%}$ \\
\hline $\begin{array}{l}\text { Impact on the } \\
\text { disease }\end{array}$ & Mitigates & Mitigates \\
\hline $\begin{array}{l}\text { Impact on the } \\
\text { symptom }\end{array}$ & Neglects & Mitigates \\
\hline
\end{tabular}

\subsubsection{The notional rate}

Some leading commentators challenge the traditional ACE literature suggestion that the best proxy for the risk-free rate is the long-term government bond rate, instead suggesting that the Belgian NID rate should reflect market conditions to enhance neutrality and growth. ${ }^{274}$ When the long-term government bond rate is used as the proxy for the NID rate, the latter will most likely be lower than the interest rate on debt financing. So, there will remain a tax preference in favour of debt financing. The author submits that this is even more problematic when there is a significant variation between the long-term government bond rate and the NID rate, as was experienced in 2011 with the Belgian NID. As shown in Figure 6 below, which depicts the Belgian NID rate since its implementation, with an additional row indicating the range of the 10-year government bond yield, ${ }^{275}$ in 2011 the long-term government bond rate reached up to $5.949 \%$ yet the NID rate applied to non-SMEs remained at $3.425 \%$.

\footnotetext{
${ }^{273}$ Cooper, above n 189.

${ }^{274}$ Høj J, 'How to Reform the Belgian Tax System to Enhance Economic Growth' (Working Paper No 741, OECD Economics Department, 18 December 2009).

${ }^{275}$ Author's own addition, see further: Fusion Media Limited, Belgium 10-Year Bond Yield, Investing.com, available at: http://www.investing.com/rates-bonds/belguim-10-year-bond-yield-historical-data
} 


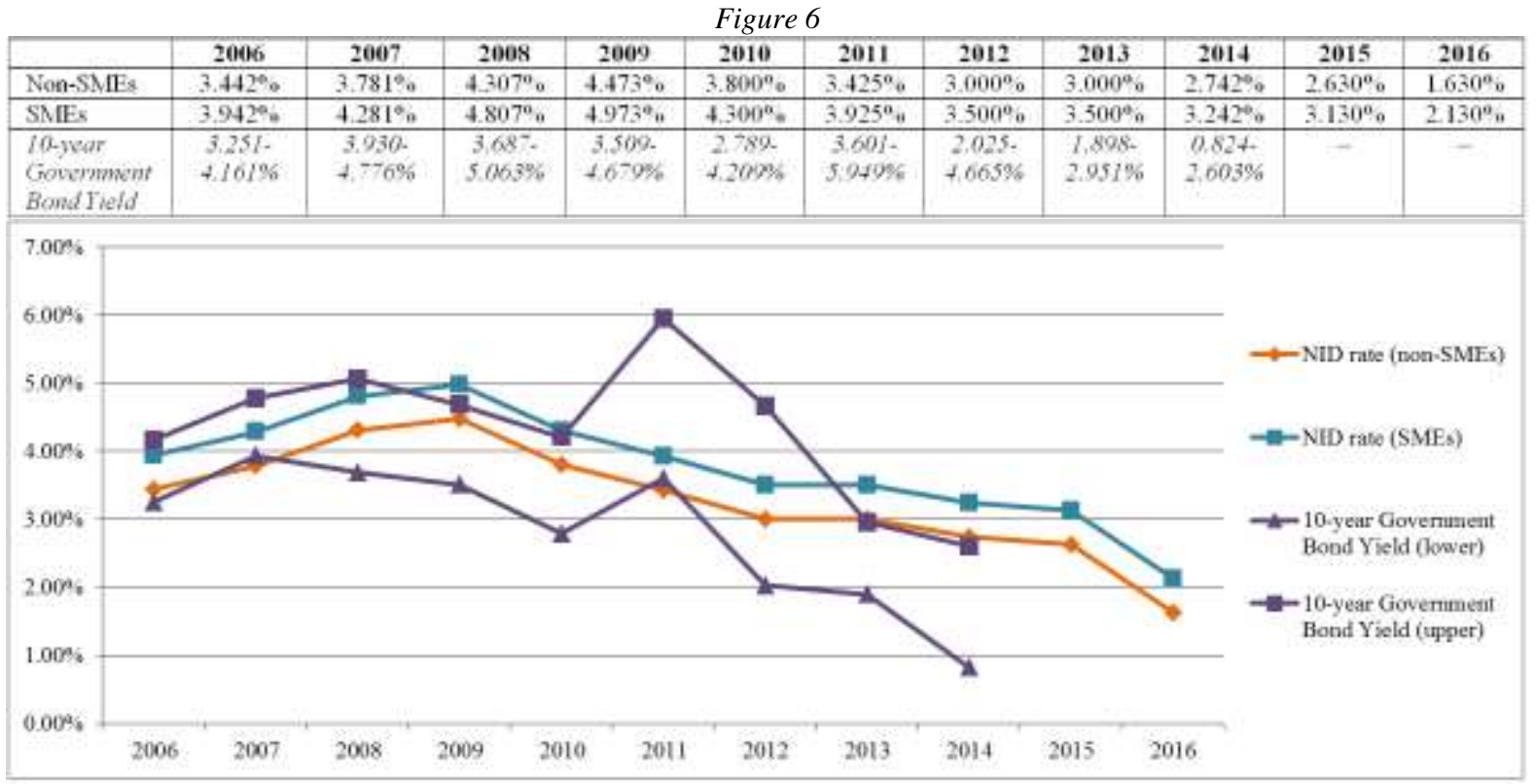

Under both the Italian DIT and the Italian ACE, empirical evidence shows that effective marginal tax rates have dramatically reduced. This is consistent with the ACE literature, which indicates that the tax advantage of debt financing can be eliminated quite simply by bringing the notional ACE rate in line with the long-term risk-free interest rate. ${ }^{276}$

The Italian DIT applied a two-tier statutory rate; the lower rate (initially 19\%, 23.25\% by early 2001) for the portion of normal profits representing the opportunity cost of new equity financing compared with other forms of capital investment and a higher rate (initially $37 \%, 40.25 \%$ by early 2001) for all above-normal profits. ${ }^{277}$ A particularly noteworthy feature of the Italian DIT was that the imputed rate was set annually with reference to market interest rates on both public and private bonds, with scope to raise the imputed rate up to $3 \%$ over market interest rates to commensurate for the higher risk of equity over debt finance, ${ }^{278}$ which seems contrary to the ACE literature suggesting that the long-term government bond rate is the appropriate benchmark rate.

Some commentators argue that the tax advantage of the Italian ACE has reduced rather than eliminated the debt bias because the ACE rate was only half the market interest rates ${ }^{279}$ in 2012 the 10 -year government bond rate was approximately $5.78-5.90 \%$. Nonetheless, by early 2014 the 10-year government bond rate had fallen to $3.10-3.40 \%$, and despite this marked decline, a larger ACE allowance was introduced under the Stability Law for 2014-16, which was applauded by leading commentators as a step in the right direction. ${ }^{280}$ For completeness, the Italian ACE literature has not compared whether the interest rates on debt financing have also halved. If they have not, this would suggest the continued asymmetric tax treatment between debt and equity financing, albeit a significantly less pronounced one.

\subsubsection{Phase-out of ACE-variants}

The 2004 repeal of the Italian DIT was attributable to the 2001 election. This political decision was criticised by some leading academics ${ }^{281}$ given the significant empirical evidence that even in its early

\footnotetext{
${ }^{276}$ Panetta, above n 248; see further Boadway and Bruce, above n 106; De Mooij, above n 93.

${ }^{277}$ Federici and Parisi, above n 146.

${ }^{278}$ Bordignon M, Giannini A, Panteghini P, ‘Corporate Taxation in Italy: An Analysis of the 1998 Reform’ (1999) 56 (3-4) FinanzArchiv: Public Finance Analysis 335.

${ }^{279}$ Panteghini et al, above n 143.

${ }^{280}$ Panetta, above $\mathrm{n} 248$.

${ }^{281}$ Panteghini et al, above n 143.
} 
stages the Italian DIT resulted in a reduction in the debt distortion ${ }^{282}$ and a reduced cost of capital. ${ }^{283}$ Admittedly, these results were based on accounting data rather than tax data, which would derive only a proxy of the increase in net equity eligible for tax purposes. So, there may have been substantial differences between net equity changes depicted on balance sheets and actual net equity changes. ${ }^{284}$

The Belgian NID has been diminishing in attractiveness, and therefore popularity. ${ }^{285}$ Over the past few years, there has been increased media pressure and pressure from all sides of politics to abolish the Belgian NID. This has resulted in the Belgian NID becoming a 2014 federal election 'hot topic'. ${ }^{286}$ It goes without saying that the tax policy uncertainty from first implementing, then modifying, phasing down, and now considering the abolition of the Belgian NID erodes business confidence. While it remains unclear whether the Belgian NID will be abolished, leading practitioners agree that abolishing the Belgian NID would diminish the attractiveness of Belgium as a destination for inbound investment. ${ }^{287}$ Further, the literature does not expressly analyse whether the watering-down of the Belgian NID provisions - thereby marking a digression from the ACE literature - was the cause of its diminished popularity. This will be examined in further research by the author.

On the other hand, at time of writing, the Italian ACE remains in operation with no indication in the literature of discontentment directed towards it.

\subsection{COMBINED ACE-CBIT}

Leading commentators De Mooij and Devereux have suggested a combination of the ACE and CBIT systems to maintain tax neutrality in relation to financing decision while also reducing possible negative effects of the pure ACE or CBIT systems. ${ }^{288}$

In terms of economic impact, a standalone ACE narrows the tax base, increases the corporate tax rate (assuming higher corporate tax rates are introduced for revenue neutrality reasons) and lowers capital costs, whereas a standalone CBIT broadens the tax base, lowers the corporate tax rate (assuming lower corporate tax rates are introduced for revenue neutrality reasons) and increases capital costs. ${ }^{289}$ It is important to note that, in the context of open economies, the ACE may inadvertently encourage profit shifting. This is due to the narrower tax base being accompanied by higher corporate tax rates, and a decrease in capital costs would attract more investment. On the other hand, the CBIT might lead to increased distortions of the marginal investment, with an increase in capital costs resulting in fewer investments. De Mooij and Devereux posit that a revenue-neutral combination of ACE and CBIT reforms in the form of the combined ACE-CBIT would improve economic efficiency by eliminating the debt bias. This suggestion has been cited with approval by the ICC, as it reflects a simultaneous movement towards limiting the deductibility of interest payments while reducing the tax burden on the cost of equity finance. . $^{20}$

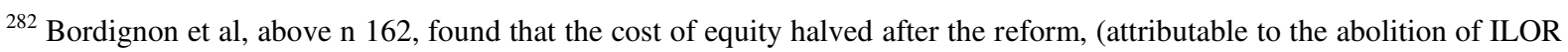
and the introduction of the DIT) and the cost of debt increased since interest payments were no longer deductible; so, while the debt bias persisted, it was largely reduced; see further, Bernasconi M, Marenzi A and Pagani L, 'Corporate Financing Decisions and Non-Debt Tax Shields: Evidence from Italian Experiences in the 1990s' (2005) 12 International Tax and Public Finance 741.

${ }^{283}$ Bordignon et al, above n 278; Staderini, above n 112.

${ }^{284}$ Santoro, above n 244; Van Campenhout and Van Caneghem, above n 152.

285 Bernstein J, 'International Tax Issues in Cross-Border Corporate Finance and Capital Markets' (2013) Tax Notes International, 2 September 2013.

${ }^{286}$ Themelin N, 'The only consequence of the announcement effects of notional interest: the legal uncertainty', Afshrift, 19 September 2013, available at: http://www.afschrift.be/en/the-only-consequence-of-the-announcement-effects-of-notionalinterest-the-legal-uncertainty.html?cmp_id=8\&news_id=2325. http://www.afschrift.be/en/the-only-consequence-of-theannouncement-effects-of-notional-interest-the-legal-uncertainty.html?cmp_id=8\&news_id=2325

${ }^{287}$ Themelin, above $\mathrm{n} 286$.

${ }^{288}$ De Mooij and Devereux, above n 95, 93-120.

${ }^{289}$ Fiscal Affairs Department, above n 64, 13-14.

${ }^{290}$ ICC Commission on Taxation, 'Limitations of deductions of interest payments' (International Chamber of Commerce Policy Statement No 180-520, February 2012).
} 
A combined ACE-CBIT consisting of a partial ACE and a partial CBIT mitigates the discrimination between both debt and equity. First referred to in $2009,{ }^{291}$ the combined ACE-CBIT has a substantial number of advantages; first, it was designed as a revenue neutral policy, and is also independent on whether the CORTAX model is extended to tax havens or discrete location choices. ${ }^{292}$ Further, economic analysis shows that moving to the combined ACE-CBIT could potentially bring substantial benefits in terms of reducing leverage, reducing systemic risk and reducing profit-shifting, ${ }^{293}$ by bringing the amount of interest close to its efficient level. ${ }^{294}$ Finally, empirical estimates suggest that the combined ACE-CBIT would raise welfare by $0.3 \%$ of GDP due to the more neutral tax treatment of debt and equity. ${ }^{295}$ Although relatively new to the literature, there is persuasive empirical evidence suggesting that the combined ACE-CBIT would expand welfare due to its more efficient financial structure. ${ }^{296}$

However, the combined ACE-CBIT has not yet been analysed in detail by the literature ${ }^{297}$ for example, in Australia, recommendations for reform have featured detailed analysis of the ACE, ACC, CBIT and DIT - entirely omitting the combined ACE-CBIT. ${ }^{298}$

Accordingly, there are significant gaps in the combined ACE-CBIT literature. The focus of subsequent research by the author will be examining whether a cross-border combined ACE-CBIT would be a viable alternative to thin capitalisation rules. This aspect remains understudied in literature.

\subsubsection{Cross-border ACE-CBIT: An alternative to thin capitalisation rules?}

A combined ACE-CBIT applicable only in the cross-border context ('cross-border ACE-CBIT') has not been contemplated by the literature to date.

An equal allowable deduction for both the cost of debt and equity financing in place of existing thin capitalisation rules is arguably a more effective and robust approach to eliminating the debt distortion in the cross-border context. The cross-border ACE-CBIT can be designed to minimise the tax revenue cost. This is demonstrated in Figure 7 below, where a particular same level of gearing generates a $\$ 16$ million tax deduction under a cross-border ACE-CBIT, a \$36 million tax deduction under thin capitalisation rules. It is important to note that $4 \%$ is a reasonable proxy for the risk-free rate, as the 10-year Australian Government bonds currently have yields around this level. Further, by applying equally to both debt and equity financing, the cross-border ACE-CBIT makes the debt and equity rules surrounding the existing thin capitalisation regime redundant, thereby simplifying this area of tax law.

\footnotetext{
${ }^{291}$ De Mooij and Devereux, above n 150.

${ }^{292}$ De Mooij and Devereux, above n 150; it is interesting that this observation was not included in the subsequent 2011 version of this paper.

${ }^{293}$ Fatica et al, above $\mathrm{n} 38$.

${ }^{294}$ Gérard M and Princen S, 'Investment and Financing Strategy of a Multinational Enterprise under Alternative Tax Designs' (CESifo Working Paper No 3838, June 2012).

${ }^{295}$ De Mooij and Devereux, above n 150; De Mooij and Devereux, above n 95.

${ }^{296}$ De Mooij and Devereux, above n 95, 93-120.

297 De Mooij and Devereux, above n 95; Marres O and Weber D, Tax Treatment of Interest for Corporations (The Netherlands: IBFD, 2013). Some commentators have suggested applying the same notional return (which strong arguments suggest should approximate some risk-free return) to equity as well as debt without referring to it as an ACE-CBIT; see, for example, Chaudhry, above n 99. The ICC has observed that, in the context of cross-border limitations of deductions of interest payments, ideally there should be neutrality between equity and debt financing from a tax point of view. On the basis of their draft scoping paper, the ICC suggested a list of recommendations be prepared and circulated to governments, noting that the sections dealing with thin capitalisation and the combined ACE-CBIT should be elaborated on and further extended to deal with technical issues. No updates have been made since: ICC Commission on Taxation, above n 290

${ }^{298}$ Sørensen and Johnson, above n 6.
} 


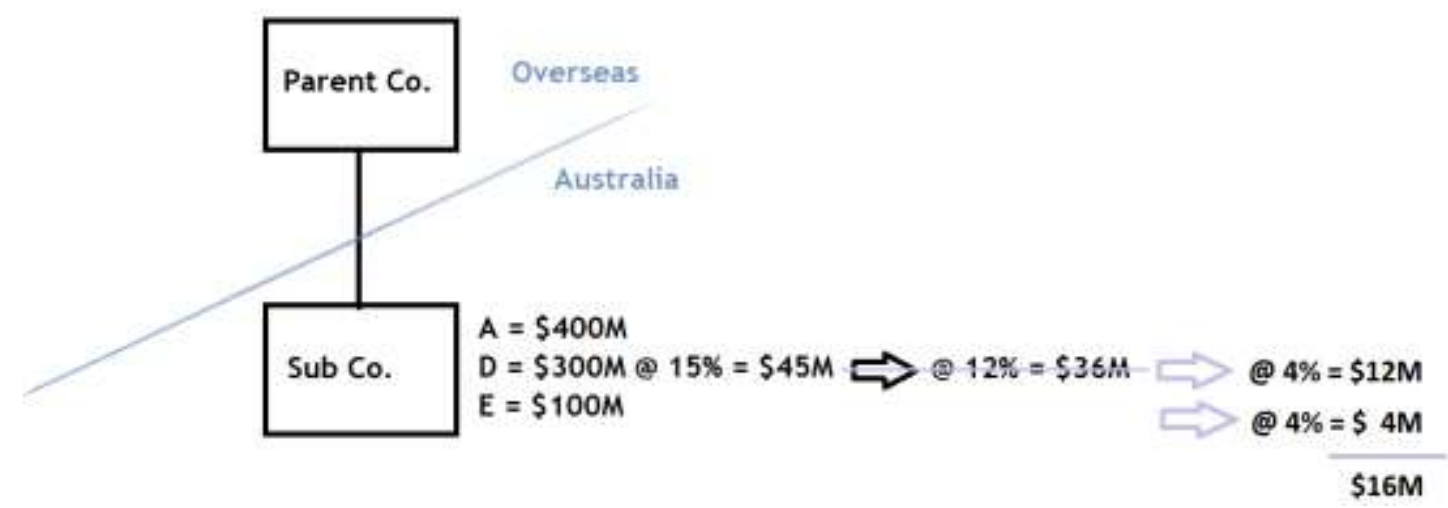

\subsection{ALLOWANCE FOR CORPORATE CAPITAL}

There exists an extensive ACC literature, a thorough analysis of which is beyond the scope of this paper. Many leading commentators have suggested an ACC reform, ${ }^{299}$ which is essentially the same as the business enterprises income tax ('BEIT'). ${ }^{300}$ These reforms contemplate an overhaul of the corporate income tax system - however the cross-border implications are largely overlooked, particularly the design aspects of international, transitional and anti-avoidance provisions. ${ }^{301}$ Indeed, to the best of the author's knowledge, none of the ACC literature suggests replacing thin capitalisation rules with an ACC applied only in the cross-border context.

The theoretical foundation for the ACC was established by Boadway and Bruce, who proposed abolishing debt deductibility and replacing it with an allowance for notional risk-free return to capital. ${ }^{302}$ A key advantage of the ACC is that it entirely eliminates the debt bias, unlike the ACE which only partially achieves funding neutrality. ${ }^{303}$ This gives the ACC the funding neutrality benefits of a CBIT without being as adverse to investments as a CBIT. De Mooij and Devereux apply simulations with the CORTAX model ${ }^{304}$ to quantify the trade-offs in ACE and CBIT reform in the European Union, the US and Japan. ${ }^{305}$ While many countries including Australia are excluded from the scope of this analysis, it may be possible to extrapolate these results to other jurisdictions.

Since the ACC treats debt and equity equally for tax purposes it arguably has the same, if not better, economic efficiency implications as the ACE. Indeed, the choice between the ACC and the ACE ultimately involves a trade-off between the greater financial neutrality achieved under the ACC and the greater real investment neutrality under the ACE. ${ }^{306}$ By applying the ACC rate on the book value of assets, the difference between debt and equity becomes irrelevant for tax purposes, thereby

\footnotetext{
${ }^{299}$ See, for example, OECD, above n 81, 134.

300 “... the BEIT uses its cost of capital allowance (COCA) system to tax investors on the normal (risk-free) return to capital and to tax businesses only on risky returns and rents. Under the COCA system, businesses obtain a uniform deduction for a normal return on their capital and pay tax on the rest of their income; investors include an assumed normal return in their taxable incomes, whether or not received by them in cash": Kleinbard ED, 'Rehabilitating the business income tax' (The Hamilton Project Discussion Paper 2007-09, The Brookings Institution, June 2007); Kleinbard ED, 'The Business Enterprise Income Tax: A Prospectus' (2005) 106(97) Tax Notes 97.

${ }^{301}$ Kleinbard, above n 300.

${ }^{302}$ The normal return is applied to the book value of the entire firm's capital according to the tax accounts, calculating net project receipts and expenses (that only include book value depreciation) and then deducting the ACC (the uplift rate) before applying the rent tax. It is thought that the ACC preserves value particularly for the spread of capital expenditure over a project's effective life: De Mooij and Devereux, above n 95, 96.

${ }^{303}$ De Mooij and Devereux, above n 95, 107.

${ }^{304}$ See further, Bettendorf L, van der Horst A, de Mooij R, Devereux D and Loretz S, 'The economic effects of EU-reforms in corporate income tax systems' (Study for the European Commission, Contract No.TAXUD/2007/DE/324, October 2009). However, CORTAX does not explicitly model tax planning through intra-company capital structures, also there is a large variation in semi-elasticity estimates for transfer pricing: De Mooij and Devereux, above n 95, 104-106.

${ }^{305}$ De Mooij and Devereux, above n 95.

${ }^{306}$ Sørensen and Johnson, above n 6, 212.
} 
reducing complexity in practice. ${ }^{307}$ However, some commentators observe that equity would then become a preferred source of finance due to the possibility of capital gains tax deferral from equity finance as opposed to interest payments and dividends that are taxable on accrual. ${ }^{308}$ Nonetheless, the OECD suggests that this non-neutrality could be addressed with a "minimum distribution rule", 309 which would induce corporations to distribute the COCA rate, be it in the form of interest payments or dividends. A weakness of the ACC is that, since it is a source-based tax system, it faces the same problems in an international context as its cash flow equivalents. So, this system may distort international location decisions and invite international profit-shifting through transfer-pricing. ${ }^{310}$

While some leading commentators compare the ACC to both the ACE and the combined ACE-CBIT, suggesting that the ACC replicates a combined ACE-CBIT, ${ }^{311}$ this may not necessarily be the case. The ACC literature contemplates the use of the risk-free nominal rate for the imputed return, applied to the book value of capital $\left(\mathrm{r}^{\mathrm{A}}\right)$, irrespective of its source of finance. ${ }^{312}$ This would effectively provide partial tax relief for both debt and equity financing, thereby equalising their tax treatment. So, the ACC would eliminate the debt bias and mitigate the behaviour of debt shifting. By equalising the tax treatment between debt and equity financing, the ACC goes one step further than the 'ACE plus thin capitalisation rules' alternative explored in section 3.2.3.

On the other hand, a combined ACE-CBIT is specifically designed to apply a partial tax deduction for the cost of both debt and equity financing. This comparison between the ACC and the combined ACE-CBIT is shown in Table 6 below. Further, it is arguable that this feature renders the combined ACE-CBIT preferable over the ACC because of its budgetary advantage, since a reduced nominal rate could have a smaller impact on the revenue base.

\begin{tabular}{|c|c|c|}
\hline \multicolumn{3}{|c|}{ Table 6} \\
\hline & $\mathrm{ACC}$ & $\begin{array}{l}\text { Combined ACE- } \\
\text { CBIT }\end{array}$ \\
\hline $\begin{array}{l}\text { Cost of debt } \\
\text { deductibility }\end{array}$ & $r^{A}=r^{\text {ribl-fiver }} \%$ & $r^{D}=r^{\text {partial }} \%$ \\
\hline $\begin{array}{l}\text { Cost of equity } \\
\text { deductibility }\end{array}$ & $r^{A}=r^{\text {ribl-freco }} \%$ & $r^{E}=r^{13 m a t h \%}$ \\
\hline $\begin{array}{l}\text { Impact on the } \\
\text { disease }\end{array}$ & Eliminates & Eliminates \\
\hline $\begin{array}{l}\text { Impact on the } \\
\text { symptom }\end{array}$ & Mitigates & Mitigates \\
\hline
\end{tabular}

\footnotetext{
${ }^{307}$ OECD, above n 81, 134.

${ }^{308}$ OECD, above n 81, 134.

${ }^{309}$ OECD, above n 81, 134.

${ }^{310}$ Sørensen and Johnson, above n 6, 202.

${ }^{311}$ De Mooij and Devereux, above n 95, 99.

${ }^{312}$ De Mooij and Devereux, above n 130.
} 


\section{CONCLUSION}

This paper approaches the issue of thin capitalisation from a novel perspective by conceptualising the cross-border debt bias as the 'disease' and thin capitalisation as merely the 'symptom'. Through a detailed review of relevant issues and the literature, it explores the lack of funding neutrality in the design of thin capitalisation rules. As summarised in Table 7 below, thin capitalisation rules are not at present a second-best solution to the tax-induced cross-border debt bias.

An analysis of fundamental reforms designed to address the debt bias is provided; in particular, a CBIT, an ACE, an ACE plus thin capitalisation rules, an ACC and a combined ACE-CBIT. The Belgian and the Italian ACE-variants provide useful case studies because they are long-standing ACEvariants still in operation, they share a closeness to the theoretical ideal, and they are relatively welldocumented. However, there is a gap in the literature regarding the more specific funding neutrality aspects of these ACE-variants and their suitability in the cross-border anti-avoidance context. Further, while leading commentators support the proposition that thin capitalisation rules would no longer be required under an ACE, the author observes that there remains a research gap in the literature on an exploration of the inverse. Specifically, whether it is possible to address the cross-border debt bias by adapting fundamental reforms into the cross-border context to improve or replace existing thin capitalisation rules. This paper extends the literature by asking whether it is possible to apply one of these fundamental reforms in the cross-border context to attain funding neutrality.

Table 7 below synthesises these reform alternatives, which were explored by way of both theoretical analysis and through the use of hypothetical examples. The most effective reform options to address both the tax-induced cross-border debt bias (the 'disease') and the behaviour of debt shifting (the 'symptom') are those that either mitigate or, preferably, eliminate the disease and symptom. While the existing thin capitalisation rules and the ACE are the only two reform options to have been implemented in practice, this paper suggests that they are not the most effective solution. Rather, either a CBIT, an ACE plus thin capitalisation rules, an ACC or a combined ACE-CBIT are preferable when considered from the perspective of the disease/symptom approach adopted in this paper. However, a CBIT would be problematic from an international investment and competitiveness perspective, and an ACE plus thin capitalisation rules model would not equalise the tax treatment of debt and equity financing. Once policy issues such as revenue neutrality and international competitiveness are considered, the reform option that this paper considers best suited to dealing with both the disease and the symptom is either the ACC or the combined ACE-CBIT.

\begin{tabular}{|c|c|c|c|c|c|c|}
\hline & CBIT & $\begin{array}{l}\text { Thin } \\
\text { Capitalisation } \\
\text { Rules }\end{array}$ & $\begin{array}{l}\text { ACE plus Thin } \\
\text { Capitalisation } \\
\text { Rules }\end{array}$ & $\mathrm{ACE}$ & $\mathrm{ACC}$ & $\begin{array}{l}\text { Combined ACE- } \\
\text { CBIT }\end{array}$ \\
\hline $\begin{array}{l}\text { Cost of debt } \\
\text { deductibility }\end{array}$ & $t^{D}=0^{\circ} \mathrm{s}$ & $\left.r^{D}=r^{c 44 p o t o}\right)_{0}$ & $r^{3}=r$ rapeda & $\mathrm{C}^{\mathrm{D}}=\mathrm{r}^{\text {anaspodo }} \theta$ & 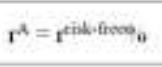 & $r^{D}=1^{\text {partid }} \sigma_{0}$ \\
\hline $\begin{array}{l}\text { Cost of equity } \\
\text { deductibility }\end{array}$ & $s^{E}=0 \%$ & $s^{E}=\theta^{n} n$ & 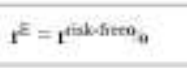 & 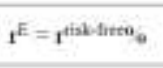 & $\mathrm{r}^{\hat{\Lambda}}=\mathrm{r}^{\mathrm{chik}} \cdot \mathrm{fros}_{\mathrm{N}}$ & $\mathrm{r}^{A}=\mathrm{t}^{\text {partialo }} \mathrm{e}$ \\
\hline $\begin{array}{l}\text { Impact on the } \\
\text { disease }\end{array}$ & Eliminates & Neglects & Mitigates & Mitigates & Eliminates & Eliminates \\
\hline $\begin{array}{l}\text { Lmpast on the } \\
\text { symptom }\end{array}$ & Eliminates & Mitigates & Mitigatex & Neglects & Mitigates & Mitigater \\
\hline
\end{tabular}

The key research gaps identified are briefly summarised as follows: first, whether it is possible to address the cross-border debt bias by adapting fundamental reforms into the cross-border context. Specifically, whether a combined ACE-CBIT reform could be utilised to improve or replace existing thin capitalisation rules. Second, whether a thorough legal comparative analysis of ACE-variants could assist in suggesting design improvements. Third, whether there is empirical support for the proposition that MNEs are currently operating at the legal limits of thin capitalisation rules. The first two research gaps are currently the focus of ongoing research by the author. 